\title{
Darwin's earthworms (Annelida, Oligochaeta, Megadrilacea) with review of cosmopolitan Metaphire peguana-species group from Philippines
}

\author{
R.J. BLAKEMORE \\ Robert J. Blakemore, VermEcology, Yokohama and C/- Lake Biwa Museum Shiga-ken, Japan. \\ E-mail: rob.blakemore@gmail.com
}

\begin{abstract}
A chance visit to Darwin allowed inspection of and addition to Northern Territory (NT) Museum's earthworm collection. Native Diplotrema zicsii sp. nov. from Alligator River, Kakadu NP is described. Town samples were dominated by cosmopolitan exotic Metaphire bahli (Gates, 1945) herein keyed and compared morpho-molecularly with M. peguana (Rosa, 1890) requiring revision of allied species including Filipino Pheretima philippina (Rosa, 1891), P. p. lipa and P. p. victorias sub-spp. nov. A new P. philippina-group now replaces the dubia-group of Sims \& Easton, 1972 and Amynthas carinensis (Rosa, 1890) further replaces their sieboldi-group. Lumbricid Eisenia fetida (Savigny, 1826) and Glossoscolecid Pontoscolex corethrurus (Müller, 1857) are confirmed introductions to the NT. mtDNA barcodes newly include Metaphire houlleti (Perrier, 1872) and Polypheretima elongata (Perrier, 1872) spp.-complexes from the Philippines. Pithemera philippinensis James \& Hong, 2004 and Pi. glandis Hong \& James, 2011 are new synonyms of Pi. bicincta (Perrier, 1875) that is common in Luzon. Vietnamese homonym Pheretima thaii Nguyen, 2011 (non P. thaii Hong \& James, 2011) is replaced with Pheretima baii nom. nov. Two new Filipino taxa are also described: Pleionogaster adya sp. nov. from southern Luzon and Pl. miagao sp. nov. from western Visayas.
\end{abstract}

Keywords. Soil fauna, invertebrate biodiversity, new endemic taxa, mtDNA barcodes, Australia, EU.

\section{INTRODUCTION}

B iodiversity assessment is important to gauge natural resources and determine regional changes. Earthworms are a crucial component of terrestrial fauna, vital for soil health and primary productivity (Darwin 1881), but their biodiversity in Australia's Northern Territory is poorly known and no comprehensive inventory yet exists. Rapid preliminary assessment is possible from inspection of museum collections and survey of botanic gardens. Both being concentrated repositories for endemic natives and introduced exotics which require considerable taxonomic expertise in order to identify correctly. The current study attempted a pilot earthworm eco-taxonomic biodiversity assessment during the author's brief visit to Darwin, the Territory's capital city, in March, 2015.

Although tropical Northern Territory occupies a vast area $\left(1,420,970 \mathrm{~km}^{2}\right)$ and an early descrip- tion was of native Diplotrema eremia (Spencer, 1896) from Alice Springs, only a dozen natives and just 8 exotics reviewed 33 years ago by Easton (1982) then Blakemore (1994, 1999, 2002, 2012a), give a present total of $c a .20$ earthworm species - about the same number as found on a single farm in the south (see Dyne 1987, Dyne \& Jamieson 2004, Blakemore 1994, 2008c).

The current report stems from a chance stopover in Darwin allowing inspection of NT Museum's entire earthworm collection as well as a day (13 ${ }^{\text {th }}$ March, 2015) assessing the biodiversity of the Botanic Gardens. An earlier brief search $\left(12^{\text {th }}\right.$ March, 2015) of likely shoreline hotspots on Mindil Beach, Fannie Bay failed to find Pontodrilus litoralis (Grube, 1855) that is known from the adjacent Harbour (Hanley 1997). Enquiries suggest quarantine excludes vermicomposting Eudrilus eugeniae (Kinberg, 1867) (see Blakemore 2015), whereas cosmopolitan exotic Metaphire bahli (Gates, 1945) was confirmed as common and 
perhaps dominant elsewhere in and around Darwin township.

Resolving simple placement of Metaphire bahli has required extensive revision as its separation from prior M. peguana (Rosa, 1890) had been contentious until molecular methods apparently allowed differentiation (e.g. Nguyen et al. 2012: tab. 1 and Nguyen 2013: 123, fig. 3.39 showing $10.7 \%$ genetic separation in Vietnam; $c f$. its misidentification by Loongyai et al. 2011 in Thailand). Relationship to Pheretima bangoiana Michaelsen, 1934 and P. saigonensis Omodeo, 1956 remained unresolved as both were listed as synonyms (priority!) of P. bahli by Thai (2000) and Nguyen (2013: 46). Superficially similar Filipino taxon Pheretima philippina (Rosa, 1891) is reviewed.

The Darwin material directly links to the author's recent Philippine studies since several exotics were found in common and some natives are seemingly also new species. However, comparison of exotics and/or natives from the Philippines is inordinately difficult it being the only country in Asia without a complete checklist of earthworm species and to further lack specific DNA data (see Blakemore 2008a: map). Plus morphological synonymy is rife and earthworm species misidentifications by non-specialists are common in Philippines as elsewhere, which may also partly account for anomalous "interspecific comparisons" of their DNA concluded by Kvist (2014). For example, Blakemore (2010) found Pheretima (Pheretima) urceolata (Horst, 1893: 322) to include: Pheretima baweanensis Michaelsen, 1924; ?P. ditheca Michaelsen, 1928; James', 2004 P. baletei, P. bukidnonensis, $P$. heaneyi \& $P$. kitangladensis; P. simsi James \& Hong, 2004; Hong \& James', 2008 P. abiadai and P. nagaensis; plus $P$. batoensis, P. bicolensis, P. buhiensis, $P$. camarinensis, $P$. doriae, $P$. gorasi and $P$. viracensis all by Hong \& James, 2009.

DNA extraction was attempted for all new material in this report. For earthworms, initial molecular treatment was by Siddall et al. (2001) with first explicit typification by Blakemore et al. (2010) using the mtDNA COI barcode standard with 3\% threshold (Hebert et al. 2003).

\section{MATERIALS AND METHODS}

Taxonomic identifications follow keys and classifications in Sims \& Easton (1972) updated by Blakemore (2000, 2008a, 2012a). New specimens in $80 \% \mathrm{EtOH}$ are lodged in the NT Museum and provided small tissue samples for mtDNA COI barcoding with preliminary analysis via NCBI-BLAST (Altshul et al. 1990) compared using MEGA6 (Tamura et al. 2013). The evolutionary history was inferred by using the Maximum Likelihood method based on the TamuraNei model (Tamura \& Nei 1993). The tree with the highest log likelihood is shown. Initial tree(s) for the heuristic search were obtained automatically by applying Neighbor-Join and BioNJ algorithms to a matrix of pairwise distances estimated using the Maximum Composite Likelihood (MCL) approach, and then selecting the topology with superior log likelihood value. The tree is drawn to scale, with branch lengths measured in the number of substitutions per site (next to the branches). The analysis involved 33 nucleotide sequences. Codon positions included were $1 \mathrm{st}+2 \mathrm{nd}+3 \mathrm{rd}+$ Noncoding. All positions containing gaps and missing data were eliminated. There were a total of 527 positions in the final dataset.

Philippine material originally in $70 \% \mathrm{EtOH}$ now in $100 \%$ Glycol intended for deposition in the National Museum, Manila is held under Fisheries Department license at UPV, Miagao Museum, care of School of Technology Dean, Dr. Emeliza C. Lozada. All PI collecting was overseen by UPV staff using my APN funds. Discussion and Conclusions are confined to Remarks after species' descriptions. Genbank accessions for Fig. 1 are in Table 1.

Abbreviations used: ANIC - CSIRO's Australian National 'Insect' Collection; APN - Asia Pacific Network; C - circumference of body; EU - European Union; $\mathrm{Fp}, \mathrm{Mp}, \mathrm{Np}, \mathrm{Sp}$ - female, male, nephro-, \& spermathecal pores; GMs genital markings; lhs, rhs - left, right hand sides; NT - Northern Territory; PI - Philippine Islands; UPV - Uni. Philippines, Visayas; PNG - Papua New Guinea; syn. - synonym; US - U.S.A. 
Table 1. Genbank Accession Numbers for Figure 1. (batch BankIt1852350)

\begin{tabular}{|c|c|c|c|}
\hline Code & Acc. No. & Code & Acc. No. \\
\hline P0 & KT626574 & P15 & KT626587 \\
\hline K1a & KT626575 & Pe1 & KT626588 \\
\hline K1b & KT626576 & Pe2 & KT626589 \\
\hline K2 & KT626577 & Pe3 & KT626590 \\
\hline P1 & KT626578 & Pe4 & KT626591 \\
\hline P4 & KT626579 & Pe7 & KT626592 \\
\hline P5 & KT626580 & Pe8 & KT626593 \\
\hline P7 & KT626581 & Pe9 & KT626594 \\
\hline P9 & KT626582 & M1 & KT626595 \\
\hline P10 & KT626583 & D3 & KT626596 \\
\hline P11 & KT626584 & D4 & KT626597 \\
\hline P12 & KT626585 & D5 & KT626598 \\
\hline P14 & KT626586 & & \\
\hline
\end{tabular}

\section{TAXONOMIC RESULTS}

Family classification of megadrile Oligochaeta Grube, 1850 s. lato (= Clitellata but see Timm 2012) as used herein follows Blakemore (2000, 2013a) rather than Gates (1972).

\section{Entire earthworm samples in NT Museum collection identified by the author}

D992: "EAST PT (Block) A/11 5/5/75 Coll. R. Pengelley." Two medium-sized Metaphire bahli (Gates, 1945).

D994: "EP RF B1 11/5/75"; "E. Pt Darwin E.P." An M. bahli mature.

D995-D1020 (excluding D1003, 1009 and 1012), D1025D1028 and D1041 were all Metaphire bahli from East Point, Darwin with collection details similar to D992.

D1021: "Moulden Palmerston NT Coll. M. Neal 25 March, 1999"; "ex soil in Moulden Staghorn Crt garden." Ca. 15 specimens, all poorly preserved, identified as M. bahli; Diplotrema sp1 and Diplotrema sp2.

D1022: Same details as D1021, M. bahli and Diplotrema sp. (too poor to describe).

D1023: "Virginia nr Darwin Coll. S. Gregg Nov 20, 1995". An immature megadrile.

D1038: "EAST POINT, DARWIN N.T. $12^{\circ} 25$ S $130^{\circ} 49$ E Coll. R. Pengelley 17 Jan 1976"; "CSIRO PT BLOCK A 17/1/76 EW." Three Diplotrema sp. (poor preservation).

D1039: "N.T. Darwin 20.xii.1992 M.B. Malipartu."; "Berlesate ex log." 18 specimens ?Amynthas sp. (poor preservation).

D1419: Described below as Diplotrema zicsii sp. n.; DNA samples D-1-2.

D1427: "W247"; "Commercial worm farm 33 Dalwood Rd, Karama NT 12²3.304'S 130 54.307'E Coll: R.W. Swan 17/03/2010". Two lumbricid Eisenia fetida.
D1530: Two M. bahli from Darwin Botanic Gardens, larger one providing DNA (D-3); coll. RJB 13 ${ }^{\text {th }}$ March, 2015.

D1528: One Pontoscolex corethrurus from Darwin Botanic Gardens DNA (D-4); coll. RJB 13 ${ }^{\text {th }}$ March, 2015 (other specimens not kept).

D1529: One M. bahli from the NT Museum grounds near the laboratory DNA (D-5); coll. RJB $13^{\text {th }}$ March, 2015.

In addition, an exotic "Dichogaster sp." (Octochaetidae, Benhamiinae) was identified in a sample (Blakemore 1995: ANIC RB.95.27.2) provided in January, 1994 by Randal Hinz from a 20year-old rehabilitated mine site in lateritic soils at Gove Peninsula, Northern Territory, characterized in Blakemore $(2002,2012 \mathrm{a})$ thus: One pair of spermathecal pores in ab lines in 8/9. Two oesophageal gizzards in $7 \& 8$, three pairs of calciferous gland in 15-17, prostates paired in 17 only with long penial setae. Spermathecal duct tapering from spheroid ampulla with small diverticulum mid-length, nephridia in approximately 10 rows per side.

Other specimens from this Gove site were cosmopolitan Dichogaster saliens (Beddard, 1893) as a new exotic record for NT plus a new native Diplotrema sp. (ANIC: RB.95.27.1) that I had at the time hoped to shortly publish contingent upon funding.

\section{Description of new and known Northern Territorian/PI taxa}

\section{ACANTHODRILIDAE Claus, 1880 sensu Blakemore 2000, 2013a}

\section{Diplotrema Spencer, 1900}

Eodrilus Michaelsen, 1907

\section{Diplotrema zicsii sp. nov.}

(Figure 2)

Material examined. Labelled: "Naididae (Oligochaeta) S. Alligator River Kakadu NP NT $13^{\circ} 31.465^{\prime}$ 'S $132^{\circ} 31.899^{\prime} E$. Coll. R.C. Willan \& party 10/07/2004." In red pen on lid: "100\% Ethanol". Two specimens, a mature - D1419, the Holotype - plus D1531 an immature Paratype ex D1419; providing tissue samples D-1 \& D-2 that due to aging unfortunately failed to yield DNA (Prof. Chris Austin pers. comm.). 
Description. Yellowy in alcohol. Size, 25 x 1.7 $\mathrm{mm}$ with 105 segments. Prostomium prolobous. First dorsal pore small in 8/9. Closely paired lumbricine setae; genital setae in 9 displaced anteriorly above ventral pads; penial setae in $17 \& 19$; setae $a b$ not found on 18. Clitellum annular 13-16 or thereabouts. GMs paired tumid pads in 9 plus elongate patch in 16/17 and two pairs of suckerlike discs in 17/18 \& 18/19 between prostatic pores and seminal grooves from 17-19. Spermathecal pores near setal $a$ lines in $7 / 8 \& 8 / 9$. Female pores paired above setae $a$ on 14. Acanthodriline male pores not located (likely in position of missing $a b$ setae?).

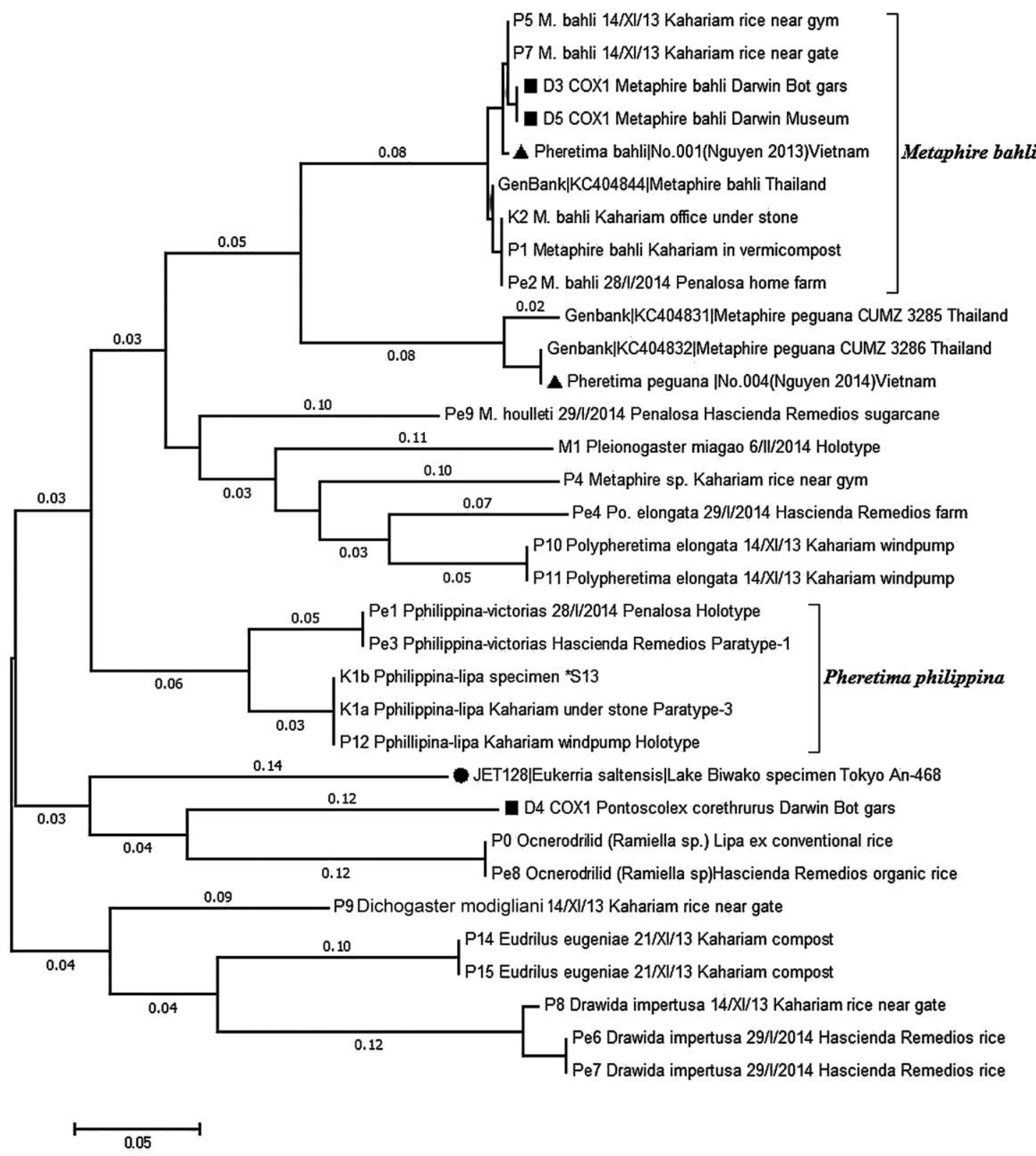

Figure 1. Phylotree from MEGA6 with specimen details in text and from Blakemore (2015) and Blakemore et al. (2014); black squares are for Darwin, triangles for Vietnam and a circle for the Japanese Lake Biwa outgroup taxon. 
Septa 4/5/6 thin, 6/7 a bit thicker, others again thin. Pharyngeal mass in 4 . Gizzard muscular in 5. Spermathecae in $8 \& 9$ as spherical ampulla on thin duct with multi-loculate, sessile diverticulum occupying duct mid-length. Genital setae overlain by spermathecae in 9 . Dorsal blood vessel single; last hearts in 13. Holandric: testes free and iridescent in $10 \& 11$; seminal vesicles in 9-12 the latter largest. Ovaries with large egg cluster in 13; ovisacs or pseudovesicles in 14. Intestinal origin in 16; no calciferous glands. Prostates with penial setae in $17 \& 19$. No tumidity noted ventrally in region of spermathecae nor male pores. Nephridia vesiculate, holoic. Gut contains colloidal material.

Immature Paratype appears to have segments 1-2 fused; moreover it lacks the GM pads in 9 but has faint markings in $16 / 17$ and pairs in $17 / 18$ \& $18 / 19$. Penial setae are present in $17 \& 19$ and no $a b$ were found on 18 in position of male pores.

Etymology. Named in tribute to Prof. Dr. András Zicsi the Hungarian oligochaete systematist of renown.

Remarks. Having seminal vesicles in 9-12, the current mature specimen most closely resembles Spencer's $D$. eremia which is itself similar to $D$. shandi Jamieson \& Dyne, 1976 from Bing Bong Road, NT. D. eremia differs however in many points, such as having several ventral GMs in some of 19/20-29/30 and twin diverticula to its spermathecae. The spermatheca of $D$. shandi are more similar to $D$. zicsii and it has a GM pad in $16 / 17$ too; however, it has extra markings in 19/20-21/22 and entirely lacks both the distinctive pads with genital setae in 9 and the paired GMs in $17 / 18$ \& 18/19. Its prostates extend through segments to 24 or 25 unlike in the current species where they are mostly confined to $17-19$, although this character is probably of lesser import.

\section{MEGASCOLECIDAE Rosa, 1891 s. stricto}

Amynthas Kinberg, 1867, Metaphire Sims \&

Easton, 1972, Pheretima Kinberg, 1867 s. stricto and Polypheretima Michaelsen, 1934 (see

Blakemore, 2008b)

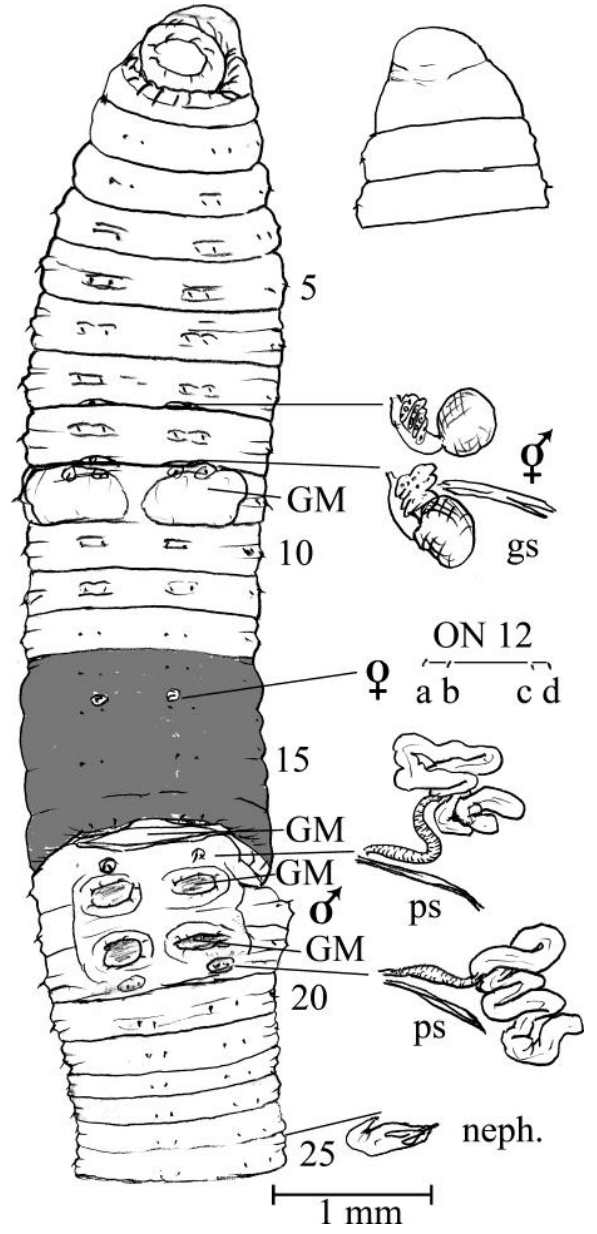

Figure 2. Diplotrema zicsii sp. nov. Holotype. gs = genital setae, $\mathrm{ps}=$ penial setae.

\section{Metaphire bahli and allied spp reviewed chronologically after a key to the species}

Note. Taxonomic differentiation between Pheretima and Metaphire is mainly on the presence of nephridia on the spermathecal ducts in the former (also sometimes found in Amynthas that, however, has superficial male pores and is the prior "default" pheretimoid genus) (Sims and Easton 1972). The function of spermathecal nephridia has not been adequately explained; perhaps they communicate with the lumen as with the enteronephric, septal nephridia first noted by Bahl (1919) for some pheretimoids or, more likely, they are exonephric, integumentary nephridia incidentally collected by developing spermathecae as they impinge through the body wall. 
Key to pheretimoids with spermathecal pores 6/7/8/9 and GMs paired within 17-19

1. Male pore superficial........................................................... 2 Male pore non-superficial ................................................ 6

2. GMs in $17 / 18 \& 18 / 19$ median to line of male pores ........ 3 GM in $17 / 18 \& 18 / 19$ more widely paired and other GMs may be present.

3. Green with fetid smell, coils in soil, spermathecal diverticula longer than ampullae.

Amynthas hupeiensis (Michaelsen, 1895) Asian cosmopolitan, common in paddy - see Blakemore (2012a) for full description.

Pale colour, very active in soil, spermathecae variable in number with diverticula short or absent.....

..Amynthas micronarius (Goto \& Hatai, 1898) from Japan \& Korea (including Jeju) - see Blakemore (2012b) for full description.

4. GMs in 17-19 also ........ A. minahassa (Michaelsen, 1896) from North Celebes.

GMs other than 17/18 \& 18/19 lacking

5

5. Male pore on discoidal porophore. .Amynthas fucosus (Gates, 1933) from Myanmar.

Male pore simple....Amynthas enkyokuan (Ohfuchi, 1951) from Sansei, China.

6. Intestinal caeca simple from 27 Intestinal caeca manicate in 27 or simple in 22 .............. 12

7. GMs paired within 18 or overtly near (one or more may be missing) GMs in $17 / 18$ \& 18/19 invaginate

\section{Metaphire bahli (Gates, 1945).}

8. Nephridia absent from spermathecal ducts........................ 9 Nephridia on spermathecal ducts

Pheretima philippina (Rosa, 1891) sub-spp from PI; GMs actually within copulatory pouch, sometimes everted on preservation.*

9. Male \& spermathecal pores ca. 0.3 or more circumference apart

Male \& spermathecal pores much closer

M. saigonensis

10. GMs sucker-like in $17 / 18 \& 18 / 19$ Metaphire peguana (Rosa, 1890).

GMs not so

11. GMs small inside $\mathrm{Sp}$ pores and/or male pores................... Metaphire houlleti (Perrier, 1872). Small GM discs equatorial $17 \& 19$.

. Metaphire posthuma (Vaillant, 1868) cosmopolitan, typically four pairs of spermathecae in $5 / 6 / 7$ /8/9 but anterior pair may be aborted as in some of its Perichaeta affinis Perrier, 1872 synonym, or further reduced.

12. Caeca manicate. ex Vietnam/Laos.

Metaphire pacseana (Thai \& Samphon, 1988) Intestinal caeca simple in 22...... Pithemera eldoni (Gates, 1975) from PNG.
* Several other Philippine pheretimoids have markings in 17/18 \& 18/19 such as Pheretima albobrunnea and $P$. incerta - both poorly described by Beddard (1912) - and Pleionogaster adya sp. nov. (as described below) but these have spermathecae in 4/5/6/7/8/9,5/6/7/8/9, and 7/8/9 respectively. Two other sexthecal/octothecal species: $P$. decipiens Beddard, 1912: 180 and $P$. benguetensis Beddard, 1912: 183 lack GMs, but data provided herein suggest these require review and possible restoration [cf. P. vaillanti (Beddard, 1890) currently in P. darnleiensis (Fletcher, 1886) that Gates (1937: 320) also recorded from "Batoran, Luzon" (= Bataan?) as "Pheretima indica"]. Sivickis (1930) studied what he identified as $P$. benguetensis from UP, Manila and from Pasig township; it is also claimed from Quezon City, Luzon. However, $P$ decipiens is the page prior species should they eventually be united, which at present I avoid doing.

It is here derived that $P$. decipiens which occasionally has spermathecae in 6/7/8/9, typically has four spermathecal pairs in 5/6/7/8/9 since Beddard (1912) compared it to members of the $P$. darnleiensis-group with four pairs in 5/6/7/8/9 and stated: the number of spermathecae (although I found only 3 pairs in one individual) serves to differentiate $P$. decipiens [also four pairs in 5/6/7/ 8/9] from P. philippina [three pairs in 6/7/8/9] and $P$. pura [two pairs in 6/7/8].

Sims \& Easton (1972: 239) put P. decipiens in a Metaphire planata-group with spermathecae in $6 / 7 / 8$, this in error I believe for two reasons: Firstly, they defaulted to Metaphire rather than to prior Pheretima if state of nephridia on spermathecae was unknown (as stated by Sims \& Easton 1972: 231); secondly, spermathecae are interpreted as being in 5/6/7/8/9 in typical decipiens from Beddard's rambling account as just noted above, thus it more properly belongs in their Pheretima darnleiensis-group.

Blakemore et al. (2007a: 29) newly put decipiens in synonymy of $P$. darnleiensis - supported at least in one of Beddard's (1912: 182) specimens having "a small accessory diverticulum" 
thought characteristic of darnleiensis. This move at that time was mainly because Sims \& Easton (1972: 261) had included P. benguetensis Beddard, 1912 under $P$. darnleiensis and because Beddard (1912: 181, 183) had repeatedly said his decipiens and benguetensis are almost identical. Both decipiens and benguetensis have enlarged setae with reduced numbers in segments 2-9 [not just in $2-8$ as claimed by Hong \& James (2010: 530)] which supposedly separated them from $P$. darnleiensis and its ilk according to Beddard (1912: 181) although Sims \& Easton's (1972: 262) redescription allowed this in $P$. darnleiensis too (cf. P. poiana Michaelsen, 1913 with spermathecae in $6 / 7 / 8 / 9$ as with the sexthecal form of $P$. decipiens).

Pheretima decipiens was differentiated from $P$. benguetensis by Beddard (1912: 182) only by smaller size (i.e., somewhat shorter than 150-190 $\mathrm{mm}$ ) and by its spermathecal diverticulum being not so long as the spermatheca itself (longer in benguetensis); perhaps also intestinal origin in 16 or 17 (but actually 16?), respectively. These characteristics also apply to sympatric $P$. cabigati Hong \& James, 2008; Hong \& James', 2010 P. pugnatoris and $P$. tabukensis; Hong \& James' 2011a P. margaritata, P. kalbaryoensis, and $P$. thaii; and $P$. barligensis Hong \& James, 2011b all potential junior synonyms of $P$. darnleiensis and/or $P$. decipiens and needing yet more work.

Note. Taxonomic 'housekeeping' requires $\mathrm{Vi}$ etnamese Pheretima thaii Nguyen, 2011 (published in March, 2011, Dr Nguyen Duc Thanh pers. comm., non prior $P$. thaii Hong \& James, 2011 from Philippines published $28^{\text {th }}$ Feb., 2011), a primary homonym named after Dr. Thai Tran Bai, be given a replacement name, here as Pheretima baii nom. nov. with author Dr Nguyen Thanh Tung's permission (Dr Nguyen Duc Ahn pers. comm. $13^{\text {th }}$ April, 2015). This species and its companion are then both transferred to Metaphire as M. baii (Blakemore, 2016) and M. mangophila (Nguyen, 2011) combs. novae.

Pheretima decipiens Beddard, 1912: 180 is herein compared in part (its sexthecal form) to new $P$. philippina sub-spp. described below. Simultaneously, Pheretima incerta Beddard, 1912: 197 is again transferred as a likely synonym of Metaphire posthuma in the description immediately following.

\section{Metaphire posthuma (Vaillant, 1868)}

(Figures 3A-D, 10)

Perichaeta posthuma Vaillant, 1868: 228, (non figs. 1-8); 1869: figs. 9-11. [Type locality Java. Types in Paris Museum, possibly AE656-668].

Perichaeta affinis Perrier, 1872: 106, fig. 66; 1875: 1044. [Type localities Saigon and Luzon, P.I. Type in Paris AE669].

Amyntas posthumus: Michaelsen 1899: 74.

?Amyntas quadripapillatus Michaelsen, 1899: 93, fig. 17 (of a spermatheca). [From Sumatra, Bindjey Estate. Types in Hamburg missing?]. Syn. nov.?

Pheretima posthuma: Michaelsen 1900: 295 (syn. affinis); Gates 1972: 212; Nguyen 2013: 56, figs. 2.5, 3.11 (syn. incerta, rhabdoida Chen, 1938).

?Pheretima incerta Beddard, 1912: 197. [From Manila, Luzon, PI. Types?].

[Pheretima rhabdoida Chen, 1938. From Hainan. Types? This is unlikely synonym as the taxon, supposedly having superficial male pores, is now held in Amynthas].

Metaphire posthuma: Sims \& Easton 1972: 239 (posthumagroup); Blakemore 2002, 2008b (syn. affinis, incerta), 2012a (syn. affinis).

Notes. Few reliable characters separate octothecal $P$. incerta from octothecal forms of $M$. posthuma, apart, perhaps, last hearts supposedly in segment 12. Sims \& Easton (1972: 237, 243) misspell subspecies name Amynthas kanrazanus incretus (Kobayashi, 1937) as "incertus" and say "(non Beddard, 1912)" confusing it with $P$. incerta, thus no replacement name is required, as already noted by Blakemore (2013b: 28). Metaphire quadripapillata (Michaelsen, 1899: 93) is similar, if not newly synonymous, too.

Charles Darwin (1881: 106) (mistakenly?) attributed to it large tower-like casts found at Nice in southern France (Fig. 3D) and it was also recorded from Kew Gardens, London by Beddard (1906) - both were new European records. Full description and distribution is provided by Gates (1972) and Blakemore (2002, 2012a). 

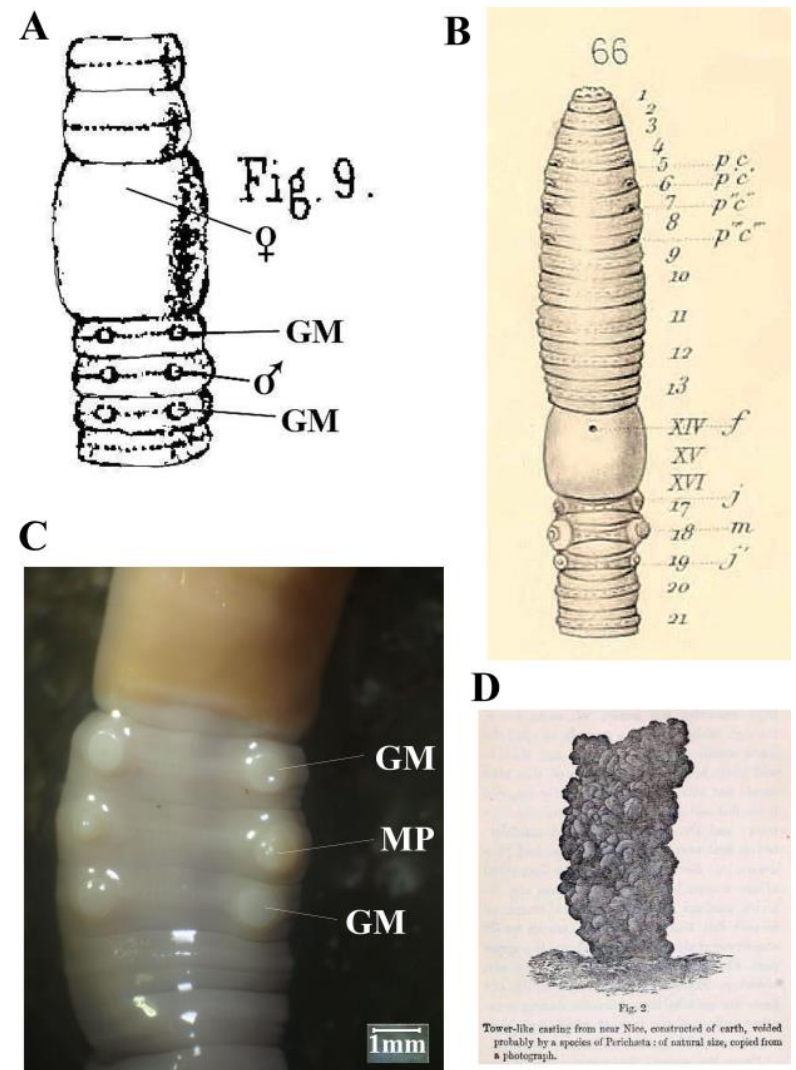

Figure 3. Metaphire posthuma (Vaillant, 1868): A = From Vaillant (1869: fig. 9); B = Synonym Perichaeta affinis Perrier, 1872: fig. 66; C = Male field photo (RJB Feb., 2014) of specimen newly record from Mindanao, PI; $\mathrm{D}=$ Casts from Darwin (1881: fig. 2).

\section{Metaphire houlleti (Perrier, 1872)}

(Figures 1, 3D, 4, 10)

Metaphire houlleti is part of a species-complex s. Blakemore (2012a) (Pheretima houlleti s. Gates 1972) thought to comprise parthenogenetic morphs distinguishable by somatic and genital characters with number of spermathecae ranging from three pairs in 6/7/8/9 to fewer in various athecal morphs (Gates 1972). Synonyms number around fifteen names, most recently including Taiwanese Amynthas huangi James et al. 2005. A cosmopolitan complex (Fig. 10) here barcoded apparently for the first time (Figs. 1 \& 4) with BLAST of JET-147 vs. Pe9 Identities = 511/632
$(81 \%)$, i.e., different taxa, confirming a molecular species-group requiring review with possible restoration of some earlier synonyms; Blakemore (2011, 2012a) provides full details. It is currently spp-group representative of more than 42 named taxa, $c f . M$. peguana spp-group of originally just three (bahli, peguana, and saigonensis) from Sims \& Easton (1972: 239).

Perichaeta houlleti $(=M$. houlleti) was also assumed by Darwin (1881: 106) partly responsible along with $P e$. affinis $(=M$. postuhuma) and Perichaeta luzonica Perrier, 1875 - a junior synonym of Lampito mauritii Kinberg, 1867 (and partly of Polypheretima elongata?) - for casts found at Nice, France (Fig. 3D). All three exotics were introduced to the EU in historical/imperial times but their current status is unknown.

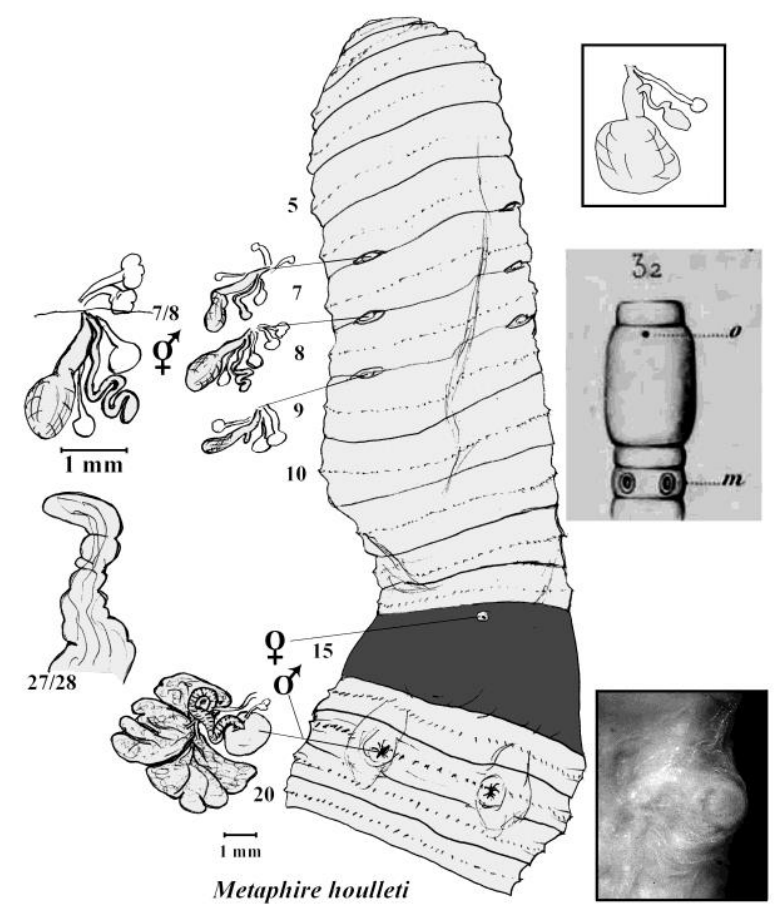

Figure 4. Metaphire houlleti species-complex: Thai specimen (Tokyo NMST An 425, DNA JET-147) compared to Perrier's original fig. 32; boxed are a spermatheca sketch and rhs male field photo of Filipino Hacienda Remedios organic canefield specimen (DNA Pe9). Note: DNA samples differed $19 \%$ suggesting different taxa. 


\section{Metaphire peguana (Rosa, 1890)}

(Figures 1, 5A-D, 10)

Perichaeta peguana Rosa, 1890: 113, figs. 6-8 (pg. 1057). [Type locality Rangoon. Types in Genoa, 44037 and, from Gates (1925: 327), in British Museum and US Museum Cat. No. 46]; Rosa 1898: 289 [augmented original account on Thailand material in London from "Chantaboon, Siam" (inspected by Beddard 1900?)].

Amyntas (Pheretima) peguanus: Michaelsen 1899: 7 (noting similarity to A. hupeiensis).

Amyntas peguanus: Beddard 1900: 628.

Pheretima peguana: Michaelsen 1900: 292, 1922: 44 (in part?); Stephenson 1923: 308, 1932: 49, fig. 5 (of spermatheca); Gates 1925: 561, 1972: 207 [syn. saigonensis; (non Ohfuchi 1957: 171 from Okinawa that is actually an Amynthas sp.)].

Pheretima (Pheretima) peguana: Omodeo 1956: 325, figs. 1, 3, 5. [?Non Michaelsen 1922: 44 (cf. M. saigonensis)].

?[Pheretima saigonensis Omodeo, 1956: 327. Locality Saigon. Types in Verona, 15].

Metaphire peguana: Sims and Easton 1972: 239 (peguanagroup); Blakemore 2002, 2003: 33, 2006, 2008, 2009: 265, 2010, 2012a. [Non Somniyam \& Suwanwaree (2009: 222) misidentification based on Somniyam (2008: figs. A, 10D, F) of another species].

Diagnosis. Bright red dorsum. 140-240 mm with 98-121 segments and 56 setae on 8 (ventral setae are larger and more widely separated). Spermathecal pores paired $c a$. 0.3 circumference apart in $6 / 7 / 8 / 9$. Male pores within copulatory pouches on segment 18. Genital markings paired rings with central apertures across $17 / 18 \& 18 / 19$. Spermathecal diverticula much coiled. Intestinal caeca simple, smooth edged from 27.

Distribution. Myanmar; Thailand; Vietnam; Cambodia (Thai \& Do 1989); Penang, Malay peninsula; Singapore; Java (Tandjong Priok, Djakarta cf. M. saigonensis); Borneo ("Lombok Bay, Labuan", i.e., Kalimantan and East Malaysia); St Paul's Cathedral Calcutta (Kolkata) and Indian Botanic Gardens at Howrah, but now (after Gates 1972: 209) excluding Japan (Okinawa). Possibly confused with $P$. bahli in the past.

Remarks. Gates (1972: 209) said that one or more of the genital markings in 17/18 \& $18 / 19$ are occasionally absent and preservation may cause eversion of male organs from copulatory pouches (cf. P. phillippina). He included saigonensis in synonymy because the differences by which it was distinguished "are quantitative, trivial, and of characters liable to more or less individual variation." However, the description by Omodeo (1956: figs. 1, 3, 5 - here as Fig. 5C vs. 5D) shows its male and spermathecal pores much closer than in $M$. peguana proper. Moreover, Omodeo (1956: 325) thought Michaelsen's (1922: 44) "P. peguana" from Java possibly refers to $M$. saigonensis which - if correct - would expanded its distribution to Indonesia. Until confirmation, I suggest confining a restored $M$. saigonensis to its type locality of Saigon (Ho Chi Minh City).

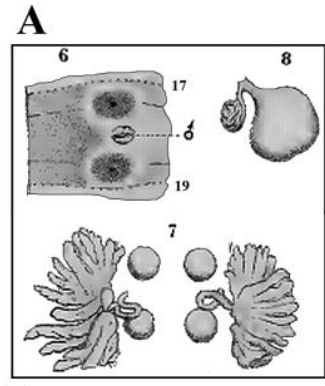

C

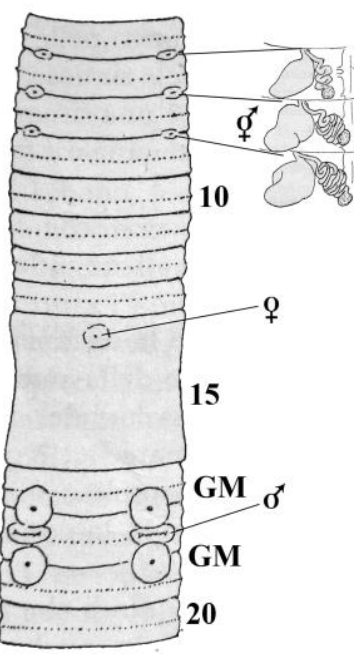

(1)
B

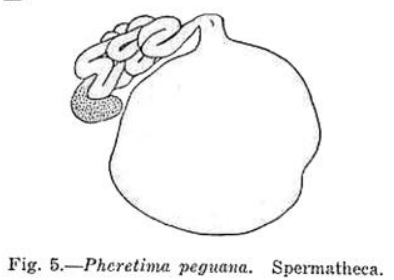

D

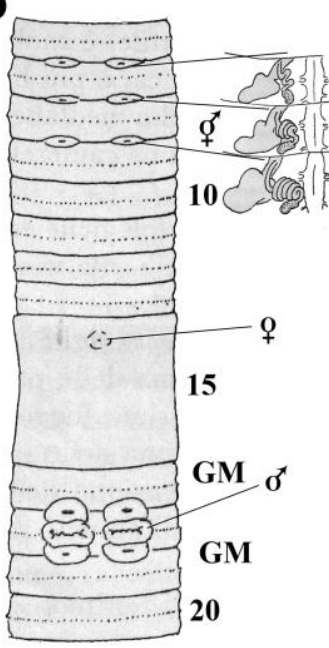

(2)
Figure 5. Metaphire peguana (Rosa, 1890). A = Rosa's figs. 6-8; B = Stephenson's (1932: fig. 5); C = M. peguana (1) cf. $\mathrm{D}=$ M. saigonensis (2) after Omodeo (1956: figs. 1-4).

\section{Pheretima (Pheretima) philippina philippina (Rosa, 1891)}

(Figure 6)

Perichaeta philippina Rosa, 1891: 397, fig. 5 (of internal male organs only). [Type locality "Insel Cebu". Types in Vienna]. 
?[Amyntas bindjeyensis Michaelsen, 1899: 94, fig. 18. Now retained in Metaphire].

Amyntas philippinus: Beddard 1900: 616 (syn. bindjeyensis). Pheretima philippina: Michaelsen 1900: 294, 1913: 89 [comparing his new $P$. poiana with spermathecae in $6 / 7 / 8 / 9$ to Metaphire merabahensis (Beddard \& Fedarb, 1895) with spermathecae in 5/6/7/8, both from Sarawak; he was likely mistaken to say the latter was probably the same as $P$. philippina]; ?non Gates 1937: 327 (see P. philippina victorias ssp. nov. below).

Pheretima (Pheretima) philippina: Sims and Easton 1972: 239 (mistakenly in a pura-group with spermathecae in 6/7/8 rather than its proper dubia-group herein replaced with a philippina-group with spermathecae in 6/7/8/9).

Description. Dark slate-coloured, black/brown. Size 180-240 x 7 mm (cf. 200-300 mm current specimens). Segments 115-125. First dorsal pore 11/12. Perichaetine with 44 setae on $8 ; 70$ setae on 12 (type). Clitellum annular 14-16. GMs absent. Spermathecal pores three pairs in 6/7/8/9 in setal lines five or six. Female pore central on 14. Male pores as wrinkled secondary pores in setal line seven or eight on 18.

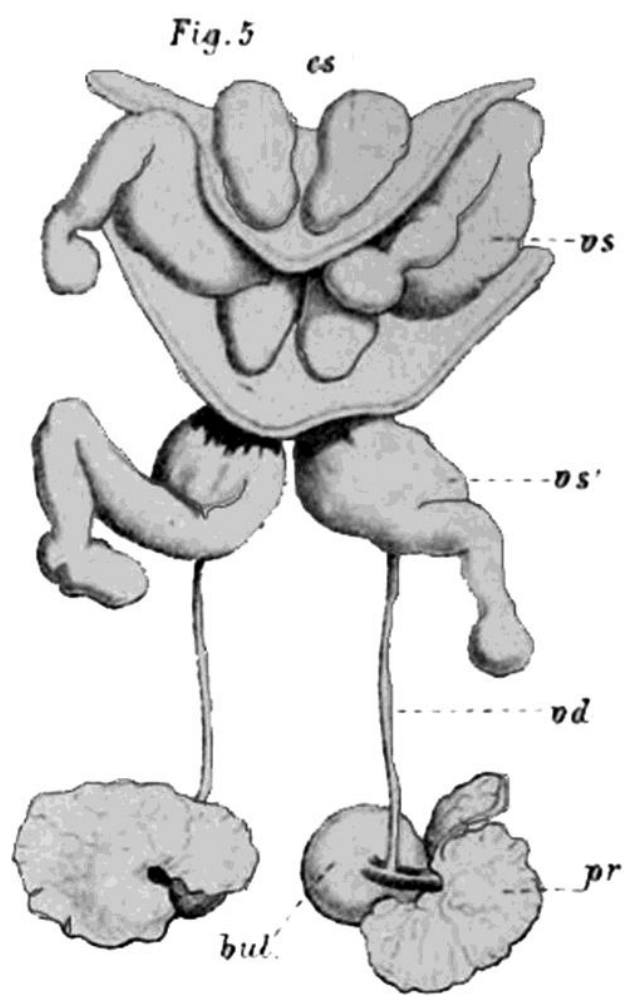

Figure 6. Male organs of sexthecal Pheretima philippina (Rosa, 1891: fig. 5) (surprisingly the only figure available for this classical, group representative species).
Septa 7/8 and 10/11/12/13 thick, 8/9/10 aborted. Crop in 7; gizzard in 8. Spermathecae in 7-9 as spherical or pear-shaped ampulla on thick duct (nephridia attached) having thin diverticulum with terminal bulb. Hearts in 10-13. Holandric: saccular testis in 10 \& 11 ; seminal vesicles in 11 \& 12 the latter pair with longer diverticula. Ovaries in 13; no ovisacs. Prostates smallish, kidneyshaped, racemose in 18 with short, unbent duct to muscular copulatory pouches. Nephridia meroic. Intestinal caeca extend for three segments from 26 (origin likely in 27).

Distribution. Cebu (type-locality); cf. Luzon and Negros Isls. (new sub-spp. below).

Remarks. Rosa said his species was similar to $P$. vaillanti (Beddard, 1890) from Manila that, however, has four pairs of spermathecae and is currently held under $P$. darnleiensis. Sumatran $P$. bindjeyensis was vouched for by Michaelsen (1913: 90) and put in Metaphire by Sims \& Easton (1972) who listed all species regardless of synonymy.

\section{Pheretima philippina-group takes priority from Sims \& Easton's, 1972 dubia-group}

Pheretima philippina Rosa, 1891 rightly belongs in Sims \& Easton's dubia-group that originnally comprised four species with spermathecae in 6/7/8/9, viz.: callosa Gates, 1937: 313, dubia (Horst, 1893: 68) and korinchiana Cognetti, 1922: 2 both from Sumatra, plus poiana Michaelsen, 1913: 88 from Sarawak and Kalimantan. However, Cognetti (1922: 2, figs. 3A-B) described $P$. korinchiana with spermathecae in either 7/8/9 (sluiteri-group) or 6/7/8/9 (philippina-group); Cognetti's figures did not show nephridia on spermathecal ducts but placement in Pheretima is likely accepted following inspection of British Museum paratypes (1927:7.30.1-2) by Sims \& Easton (1972: 180).

Gates (1937) described $P$. callosa on a specimen (330 mm long) from Benguet, northern Luzon, separating it from (his concept) of $P$. philippina on a few anatomical points (noted under description of $P$. philippina lipa ssp. nov. below). 
Five "dubia-group" Pheretima from northern Luzon, PI were added by Hong \& James (2010, 1011a, b), viz.: P. balbalanensis \& P. banaoi from Kalinga Province; $P$ globosa from Ilocos Norte; and P. lamaganensis \& P. julkai from Mountain Province - all of which are small and similar (synonyms?) that they nevertheless thought different to $P$. philippina (and P. callosa?). Having spermathecae impinging either before or after a septum is largely incidental and irrelevant taxonomically, e.g., these varied intraspecifically in $P$. decipiens Beddard (1912: 182) and P. monticola Beddard (1912: 197) and are often seen in other species (pers. obs.). Hong and James (2011b: 24) misinform that $P$. philippina type-locality is Mindoro.

Taxonomic note. Pithemera glandis Hong \& James, 2011a is clearly a new synonym, along with Pi. philippinensis James \& Hong, 2004, of prior Pi. bicincta (Perrier, 1875) from Luzon. Also their Pheretima aguinaldoi and/or P. banaoi and Pithemera levii are incertae sedis as Hong \& James (2010: fig. 2 cf. figs. $3 \& 4$ and 2011b: fig. 7) have obviously miscounted segments.

DNA data (Fig. 1) is newly provided for $P$. philippina that, however, shows genetic differences of $>8 \%$ indicating likely separate taxa. Since neither group is from the nominal typelocality (Cebu Island), and it is not certain that Gates was dealing with typical material from Negros Is. either, they are both here named at sub$\mathrm{sp}$. level pending fuller resolution. Descriptions of these two newly proposed $P$. philippina-group taxa follow.

\section{Pheretima philippina lipa ssp. nov.}

(Figures 1, 7A-J)

?Pheretima decipiens Beddard, 1912: 180 part (specimen with "only 3 pairs" of spermathecae thus likely compliant with philippina-group). [From 1,524 $\mathrm{m}$ at Benguet, Luzon as for benguetensis from Beddard (1912: 183). Types missing].

Material examined. Holotype, UPV specimen code \#S24 mature, $300 \mathrm{~mm}$ long, sketched and dissected providing DNA tissue sample (P12) from beside wind-pump and water tank next to caribou wallow at Kahariam organic farm Lipa City $\left(13^{\circ} 56^{\prime} 28^{\prime \prime} \mathrm{N} 121^{\circ} 09^{\prime} 44^{\prime \prime} \mathrm{E}\right)$, Batangas, PI; coll. $14^{\text {th }}$ Nov., 2013 by RJB \& Rowena Ocenar; Paratype-1 \#S25 slightly smaller specimen (200 $\mathrm{mm}$ long) from same batch that agrees superficially (no DNA); Paratype-2 \#S26: same batch, mature $200 \mathrm{~mm}$ long with everted male pores, providing DNA (code P13 that, due to avoidable UPV delay in sending, yielded no result); Paratype-3 \#S14 aclitellate mature, $200 \mathrm{~mm}$ long, dissected and providing DNA sample (K1a) from under stone beside farm office coll. RJB $14^{\text {th }}$ Aug. 2013; Paratype-4 \#S19 mature $245 \mathrm{~mm}$ long from rice paddy near shooting range (DNA P6 nil result) coll. $14^{\text {th }}$ Nov. 2013. Specimen UPV \#S13 mature $(310 \mathrm{~mm})$, dissected providing DNA ("K1b") from greenhouse at Kahariam in vermicompost, $22^{\text {nd }}$ Nov. 2013 by UPV staffers.

Diagnosis. Large worm with dark dorsum but paler intersegments and setal auriolae. Complying with nominal species except size range slightly larger (viz. ca. $200-300 \mathrm{~mm}$ by $5.5 \mathrm{~mm}$ ), first 9 segments are darker with larger setae (as per $P$. decipiens), pro-epilobous prostomium, dorsal pores from $12 / 13$, setae ca. $40-50, c a$. four or six setae between male pores. Copulatory pouch contains two genital pads either side of the penis, which may be everted on preservation, as seen in Paratype-2. Septa 8/9/10 aborted. Peptonephridia in 4-6. Spermathecae in 7-9 as spherical ampulla on thick duct (with nephridia attached) having straight or slightly wavy diverticulum almost to tip of ampulla with terminal bulb. Seminal vesicles in $11 \& 12$ have appendages. Last hearts are in 12 (or 13 in \#S13). Prostates on short duct. Intestine from 16; caeca thin and simple from 27; gut contains soil rather than litter.

Etymology. After type locality near Lipa City, Batangas.

Distribution. Southern Luzon (and more northerly for "decipiens" specimen?).

Remarks. The two prior sexthecal species from Philippines are P. philippina (Rosa, 1891) from Cebu (plus Gates' 1937: 327 claim from Negros 


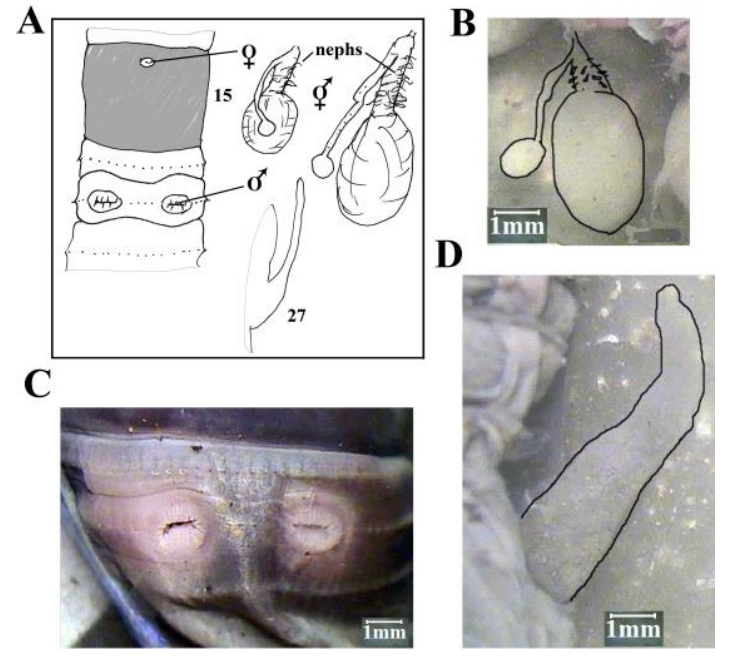

Figure 7. Pheretima philippina lipa ssp. nov. Holotype (\#S24, DNA P12) with male pores retracted. A = Male field sketch with 9lhs spermatheca (plus enlargement) and intestinal caeca; B-D =photos of same with organs outlined.
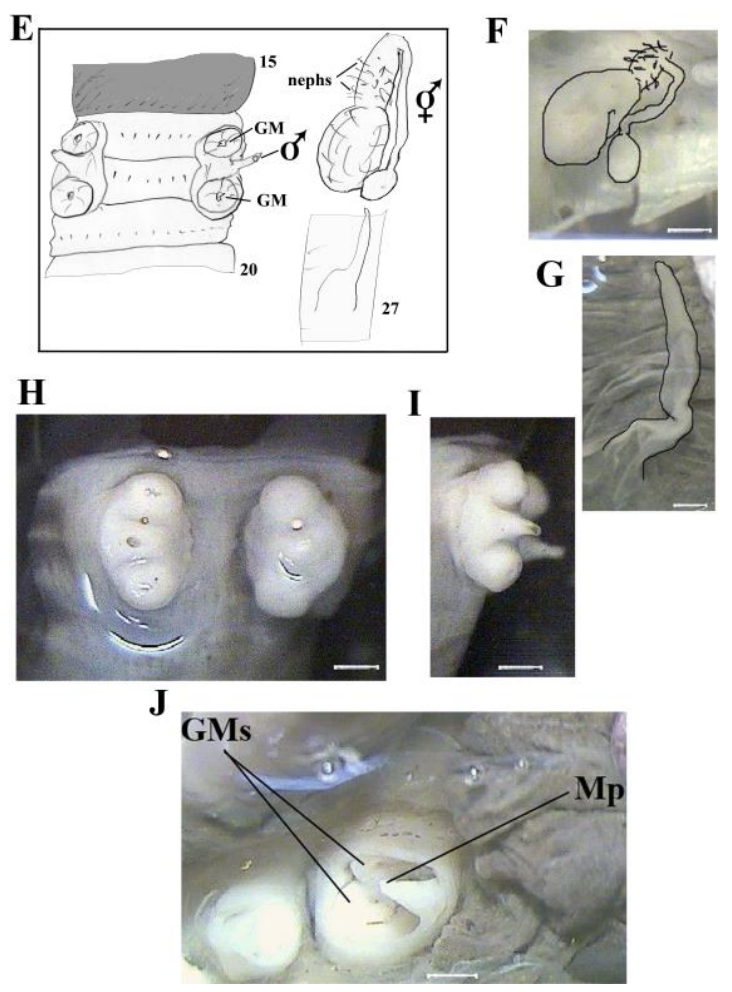

Figure 7. Pheretima philippina lipa ssp nov. Paratype 2 (\#S26) with everted male organs: E = Sketch of male field, spermatheca and caecum; F-I photos of same with organs outlined; $\mathbf{J}=$ Specimen \#S13 (DNA K1b) copulatory pouch sectioned with enclosed penis to male pore $(\mathrm{Mp})$ and $\mathrm{GMs}$ either side. DNA K1b matched Holotype's (P12) and other sample $100 \%$ - see Fig. 1.
Occidental but see $P$. philippina victorias ssp. nov. below) and P. callosa Gates, 1937: 313 from Benguet both of which were thought closely similar. In fact Gates (1937: 315, 329) differentiated his new species callosa only by its larger size (330 by $16 \mathrm{~mm} v s$. ca. $120-240$ by $8 \mathrm{~mm}$ ), the larger setal numbers (70-114 vs. 36-70), the rudimentary condition of septum 8/9 (which however was variable), a vertically cleft penis tip, and the binding together of loops of the spermathecal diverticula (in P. callosa). The diverticulum in $P$. philippina is typically more straight (and some of the other characters apply more to $P$. p. victorias).

On balance the current specimens comply with $P$. philippina rather than $P$. callosa; slight differences are that the last hearts were in 12 (13 in nominal taxon and S13) and that the intestine commenced in 16 in current specimens (rather than 15 in Gates's specimens - see P. p. victorias). Some characters merge with those of $P$. callosa but the spermathecal stalks are straight and the setae apparently fewer; moreover, $P$. philippina has priority should these two taxa eventually merge.

The present sub-species has setae fewer in the anterior and numbering about 40-50 after segment 9 (agreeing with $P$. decipiens); spermathecae in 7-9 with straight diverticula, and septa 8/9/10 aborted, i.e., different to $P$. callosa. The DNA COI barcode, that had no close match on Genbank, is definitive for the new holotype.

\section{Pheretima philippina victorias ssp. nov.}

\section{(Figure 1)}

?Pheretima philippina: Gates 1937: 327. Supposed new mateial from US Nat. Mus. Cat. No. 20152 one mature specimen "V A18 Adodolay [sic]. Md X. Balabag Silay. Occ. Negros. 12/11/29. No. 109780" and Cat. No. 20153 two matures from "Negros Is. P.I. Bashford Dean. No. 38683." Note that "Adudulay" is the Ilonggo name for the large black native worms (Delia deGuzman at Hacienda Remedios, pers. comm. Jan. 2014; cf. Polypheretima elongata name).

Material examined. Holotype, UPV specimen code \#P1 large, dark, subadult providing DNA 
tissue sample ( $\mathrm{Pe} 1)$ from Peñalosa home farm/ shop Victorias City $\left(10^{\circ} 54^{\prime} \mathrm{N} 123^{\circ} 05^{\prime} \mathrm{E}\right)$, Negros Occidental, PI; coll. $28^{\text {th }}$ Jan., 2014 by RJB; Paratype-1 \#P3 large, dark mature DNA sample (Pe3) collected same day from Hacienda Remedios organic farm on road beside woodland with many worm castings; Paratype-2 \#P5 29 ${ }^{\text {th }}$ Jan., 2014 HR farm in rice paddy embankment (DNA Pe5 gave no results two months later); other specimens from canefields, paddy and vegetable plots (not kept).

Other material? Apart from Gates' specimens noted above, US Cat. No. 27587 one Pheretima specimen from "Hda. Bacayan, Victorias, Occ. Negros. Philippine I. Va2 12/8, 1927 W.D. Pierce $G C$ [Good Condition] Id. G.E. Gates, 1957 Acc. No. 106537."

Diagnosis. Complying tolerably with nominal species morphologically, Gates' specimens were perhaps a bit shorter $(122-197 \mathrm{~mm})$ with fewer setae numbering 36 on 8 then to 53-64 (Gates). First dorsal pore was in 12/13 but Gates found a pore-like marking in $11 / 12$ too. Other possible differences described by Gates are presence of thin septum $8 / 9$ and intestinal origin in 15 . In one of Gates specimens the copulatory chamber was partially everted exposing posterior GM protuberance. Septum 8/9 was present but 9/10 was lacking. The slender diverticulum typically extends to or beyond ampulla tip (unlike in P. p. lipa) and has a seminal chamber of variable shape (Gates).

Etymology. After type location near Victorias City, Negros.

Distribution. Northern Negros Occidental, PI.

Remarks. The DNA barcode data define this taxon separate from the other new sub-sp. (>8\%, Fig. 1). Differences from $P$. callosa Gates, 1937 have already been explained.

\section{Amynthas bangoianus (Michaelsen, 1934)}

\section{(Figure 8)}

Pheretima (Ph.) bangoiana Michaelsen, 1934: 505, fig. 6-8. [From Cam Rahn Bay (Port of Ba Ngoi), Vietnam. Type in Paris (576)].
Amynthas bangoianus: Sims and Easton 1972: 236 (sieboldigroup); Blakemore 2008b.

Remarks. Michaelsen (1934: 508) states that male pores are simple and that "Kopulationstaschen" are absent, thus belonging in Amynthas rather than Metaphire. In addition, its GMs are clearly quite separate from those typical of $M$. bahli (Gates, 1945) and it is thus removed from supposed synonymy even though it had priority!

Taxonomic note. Sims and Eastons' group taxon, previously Amynthas sieboldi (Horst, 1883) that was transferred to Metaphire by Blakemore (2003: 34, 2011: 10), is hereby replaced by next prior group representative: Amynthas carinensis (Rosa, 1890) as a new carinensis-group comprising about 50 taxa, including A. bangoiana, listed by Sims and Easton (1972: 236) and Easton (1979: 119).

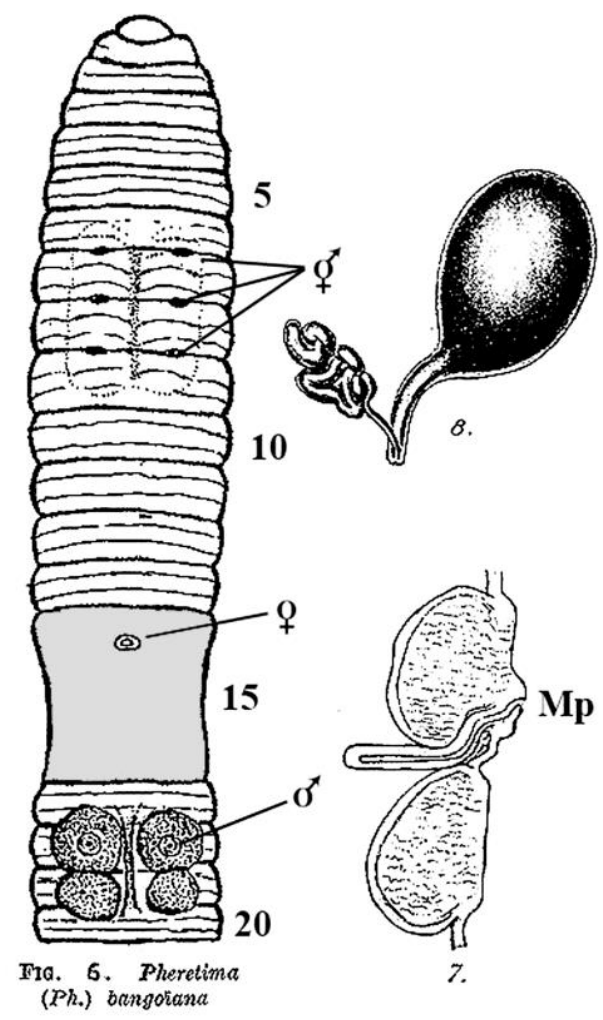

Figure 8. Amynthas bangoianus (Michaelsen, 1934: fig. 6-8) (Mp - superficial male pore). 


\section{Metaphire bahli (Gates, 1945)}

(Figures 1, 9A-D, 10)

Pheretima bahli Gates, 1945: 85. [Type locality Colombo, Sri Lanka. Types, supplied by Kirtisinghe (as P. peguana), originally in Prof. Bahl's collection, now lost]; Gates, 1972: 209; Thai, 2000 (part. with supposed syns. saigonensis, bangoiana).

?Pheretima sp. Gates 1972: 210. [Believed from Thailand; male field more depressed than usual in M. bahli (cf. $M$. peguana, M. pacseana, M. saigonensis)].

Metaphire bahli: Sims and Easton 1972: 239 (peguanagroup); Easton 1982: 730, fig. 4f; Blakemore 1994: 364, 1999: 187, 2002, 2008b, 2009: 265, 2012a.

Material examined. UPV sample \#S15 clitellate mature, $135 \mathrm{~mm}$ long, dissected and providing DNA sample (K2) from under stone beside farm office Kahariam farm, Lipa City, Batangas, coll. RJB 14 ${ }^{\text {th }}$ Aug. 2013; \#S16 mature 95+ mm long (DNA P1), from same location but in vermicompost beds coll. RJB \& RO $14^{\text {th }}$ Nov. 2013; also same day \#S18 one of three specimens, $105 \mathrm{~mm}$ long from rice paddy near gym (DNA P5); \#S20 mature from rice paddy beside gate (DNA P7); plus \#P2 longest of four matures providing DNA (Pe2) Penalosa farm, Victorias coll. RJB $28^{\text {th }}$ Jan. 2014; and \#S31 two matures (both length $=120 \mathrm{~mm}$ ), from Hacienda Remedios farm, Negros in cane/banana grove coll. RJB $30^{\text {th }}$ Jan. 2014. Other specimens inspected from Darwin Museum, NT are presented in Results section above.

Diagnosis. Red-brown colour. 110-150 x ca. 4-6 mm. Metaphire with paired spermathecal pores 0.25 (Easton, 1982) or $<0.5 \mathrm{C}$ (Gates, 1972) apart in 6/7/8/9. Diverticula coiled with terminal bulb. Paired GMs in line with male pores in 17/18 \& 18/19 always invaginate (cf. M. peguana). Intestinal caeca simple.

Distribution. Sri Lanka, the Philippines [previously from Manila and Clark Field (= Angeles City; Gates and pers. obs.), Sual (Pangasinan) and Sibuyan Island (US NMNH Museum specimen), currently from Batangas and Negros as new records], Laos, Vietnam (Thai \& Samphon 1989), Cambodia (Thai \& Do 1989 and pers. obs. at Angkor Wat Temple, $11^{\text {th }}$ Nov., 2003), Thailand

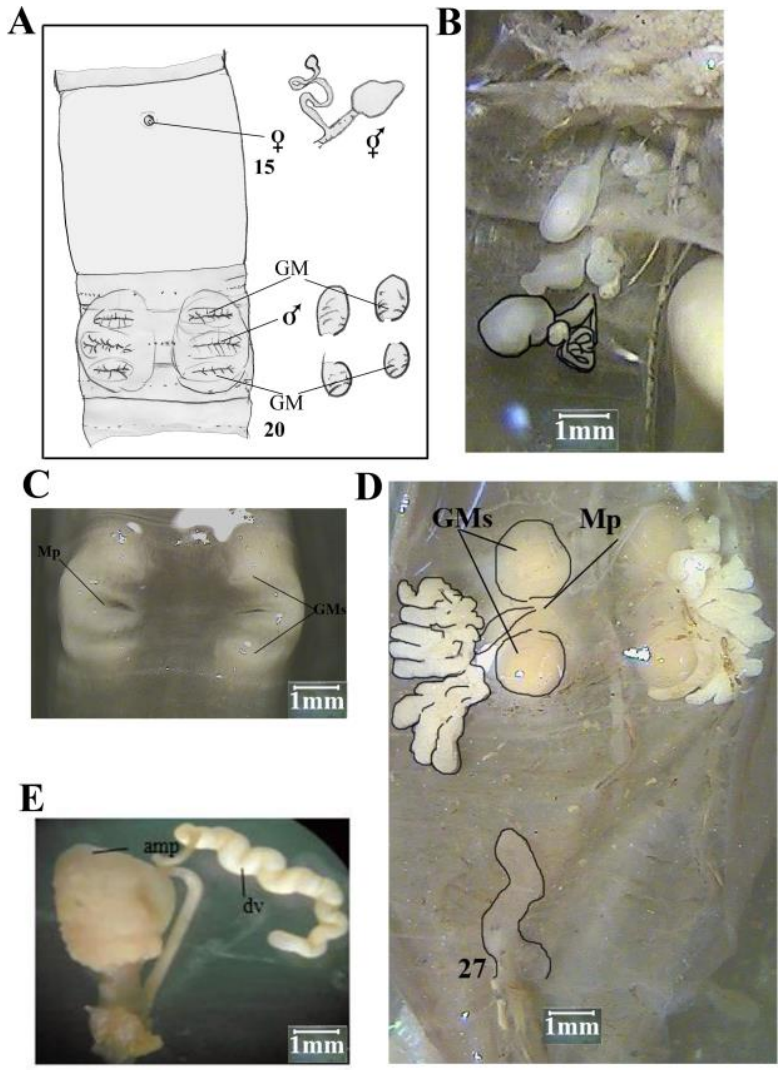

Figure 9. Metaphire bahli (Gates, 1945). A = Male field and spermatheca (Darwin specimens); B-D = photos of same from

Kahariam \#S15 with organs outlined; $c f$. $\mathrm{E}=$ Metaphire pacseana (Thai \& Samphon, 1988) from

Nguyen (2014: fig. 1B).

(Gates 1972: 210, Blakemore 2008a and information in Introduction above), and from northern Australia. Its records in Australia are from around Darwin, NT (Easton 1982): from Snake Bay, Melville Island, Elizabeth River $8 \mathrm{Km} \mathrm{S}$ of Darwin and beside Manton River $60 \mathrm{Km} \mathrm{S}$ of Darwin; in current studies it was found exclusively in the central Bicentennial park of Darwin through to the Botanic Gardens there with many specimens in drainage ditches or dried on pavements. Gates (1972) thought that the original home may be centered in what is now Thailand/Laos and other records were by introduction. Interestingly, Gates (1972: 210) noted that M. peguana and M. bahli had not been recorded from the same locality, although Thai \& Samphon (1989: 75) and Nguyen (2013: tab. 3.1) recorded them both in Mekong Delta sites in Vietnam (Blakemore et al. 2007b: 29). 

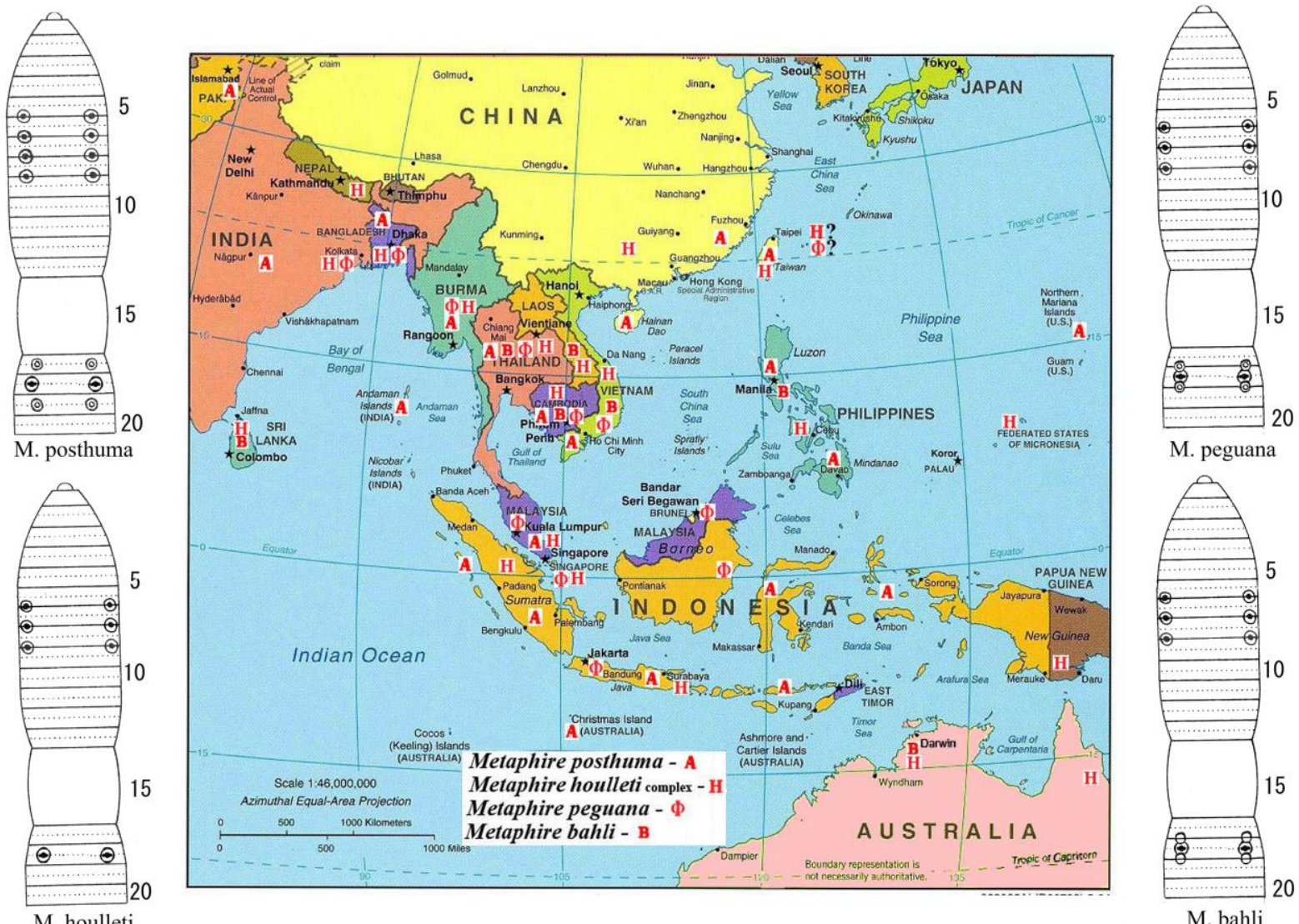

M. houlleti

M. bahli

Figure 10. Indo-Australasian distribution of tropical cosmopolitan Metaphire spp. (Asia map courtesy of CIA: http://www.loc.gov/item/2004627975/\#about-this-item).

Ecology. Current studies found M. bahli with organic sugarcane, rice and bananas in PI and in Darwin Botanic Gardens in vicinity of introduced plants including teak (Tectona grandis L.) itself native to Thailand/Laos and introduced to Sri Lanka by the Dutch in 1680. If associated with teak plantations it may be expected in Africa and the Caribbean too, but this is just one of many possible means of transportation of what may now be considered such a major cosmopolitan species. Habitats are variable: $e . g$, parks, fields, woodlands, paddy and in vermicompost wormbeds (Kahariam farm, Batangas). Associated with presence of this worm is rich, well drilled topsoil with copious surface casts in Darwin Gardens where it is predated by Bush Turkey, Megapodius reinwardt Dumont, 1823 (pers. obs.), i.e., at least partly a litter dweller, partly a topsoil species. Refuerzo and Reyes (1959) reported it in Philippines as an intermediate host of nematode Metastrongylus apri (Gmelin, 1790) [syn. Metastrongylus elongatus (Dujardin, 1845)] lungworms parasitic in domestic pigs or wild boars, occasionally infecting ruminants and, rarely, humans.

Behaviour. Usual 'snaking' escape response. Field identification by slight pressure around male pores causes eversion of these plus GMs to give a 6-pointed star formation.

Remarks. Full description is provided in Blakemore (2012a). A Vietnamese paper by Thai (2000) repeated in $\mathrm{PhD}$ thesis by T.T. Nguyen (2013: 46) suggested Pheretima bahli synonyms of Metaphire saigonensis (Omodeo, 1956) and Amynthas bangoiana (Michaelsen, 1934) but if it were so, then the latter species would have taken priority from Gates' bahli, as briefly summarized 
above. The current study counter-indicates their mutual inclusion as GMs differ at least; moreover, it is now well defined genetically.

Metaphire pacseana (Thai \& Samphon, 1988)

(Figure 9E)

Pheretima pacseana Thai \& Samphon, 1988: 8. [From Pacse, Laos and ?Vietnam. Types?].

Metaphire pacsana : Blakemore, 2008b: 74.

Remarks. Thai and Samphon $(1989: 64,75)$ argued that their pacseana from Laos explained the relationship between $M$. bahli and M. peguana: It has similar markings $17 / 18 \& 18 / 19$ but is larger, up to $270 \mathrm{~mm}$ long, with diverticulum twice the length of the ampulla plus duct (no nephridia), and a deeply incised and multiple intestinal caeca. Tentative placement in Metaphire by Blakemore (2008) is supported by a photograph in Nguyen (2014: fig. 1B) lacking nephridia on the spermathecal duct (although he yet lists it as " $P h$. pacseana Thai, 1987”) - see Fig. 9E.

\section{Polypheretima elongata (Perrier, 1872) species- complex}

(Figure 1)

Polypheretima elongata complex: Sims \& Easton 1972: 252, Easton 1976, 1979.

Comprising: acystis, annectens, barami, baritoensis, biserialis, bonensis, elongta, everetti, kinabaluensis, klabatensis, koroensis, mahakkami, monocystis, phacellotheca, sarawacensis, seriatus, stelleri \& tinjarana.

Material examined. From current studies, UPV \#S23 three worms in clay near wind-pump at Kahariam farm coll. 14.XI.2013 by RJB \& RO (DNA P10-11 from a mature and an immature specimen); mature specimens \#R2 from clay at wind-pump and \#R3 in sand by stream both collected $21^{\text {st }}$ Jan. 2014 RJB \& RO (DNA taken but not sent for testing by UPV); \#P4 three specimens, two matures up to $500 \mathrm{~mm}$ long from rice and one medium specimen from cane at Hacienda Remedios coll. $28^{\text {th }}$ Jan., 2014 RJB (lat- ter specimen provided DNA sample Pe4); \#S30 five matures from Tagbac farm, Orton in rice paddy coll. $12^{\text {th }}$ Feb., 2014 by UPV staffers \& RJB (DNA sample T1 not sent to lab by UPV).

Other material. Gates (1937: 318) mentions specimens from Batoran, Luzon and Negros Island; plus US Nat. Mus. Cat. No. 28711 has one specimen of Pheretima elongata (Perrier) labelled "Lago, Bacayen, Victorias, Occ. Negros, canefield soil. VA17 July 8, 1927 W.D. Pierce GC [Good Condition] Id. G.E. Gates 1957 Acc. No. 109780". Note "Lagu" is the Ilonggo name for long, pale worms (cf. Ph. p. victorias name). Easton (1976: 51) has elongata specimens from Bataan, Luzon, Mindoro and Manila including "BM(NH) 1904:10.5.1-2 (biserialis: Beddard, 1890 ; syntypes of acystis)".

Remarks. Full ecological and taxonomic descriptions of this cosmopolitan species-complex are provided by Easton $(1976,1979)$ and Blakemore $(1994,2002,2012 a)$ wherein its misidentification in India for vermicomposting is noted. Although only the nominal species is now reported from the Philippines, BLAST analysis of the DNA data presented here shows $>11 \%$ difference thus review/restoration of its components is warranted. Consideration should also be give to supposed natives such as Polypheretima monticola (Beddard, 1912: 195) from Mt Pulong, Luzon that was itself poorly characterized and is without known types. It was described as $130 \mathrm{~mm}$ long with spermathecae paired in 5/6/7/8/9 and GMs paired in $9,17 \& 19-20$ in one specimen but not so developed in the other. In this regard this second specimen is the same as Po. bannaworensis Hong \& James, 2008 which may thus be in synonymy; one other of their Filipino species, $P o$. fruticosa, is incertae sedis as the segments are again miscounted in Hong and James (2008: fig. 2A).

\section{Description of two new native Pleionogaster species from Philippines}

The opportunity is here taken to describe two taxa of the author's concurrent PI studies. 


\section{MEGASCOLECIDAE Rosa, 1891}

Genus Pleionogaster Michaelsen, 1892

Type: Pl. jagori Michaelsen, 1892 (non horsti Beddard, 1886, see Easton, 1979: 114).

\section{Pleionogaster adya sp. nov.}

(Figures 11A-D)

Material examined. UPV\#S3: Holotype, quiescent mature (DNA sample W2) found coiled in alluvial soil of banana grove $(13: 52: 14.31323 \mathrm{~N}$ 121:8:42.36106E) at Kahariam organic farm, Brgy. Adya, Lipa City, Batangas, Luzon; coll. RJB 28 ${ }^{\text {th }}$ Mar., 2013. [Specimens?: \#R5 two matures from sand beside adjacent stream (possibly a different species), coll. RJB \& RO $21^{\text {st }}$ Jan., 2014 (DNA R5)].

Description. Unpigmented. Size 145 by $5 \mathrm{~mm}$. Segments $c a$. 100+. Prostomium prolobous. First dorsal pore 11/12. Setae numerous $>100$ per segment. Nephropores, eight per side (as dark gaps in setal arcs). Spermathecal pores in 7/8/9 ca. $0.25 \mathrm{C}$ apart. Female pores on 14. Male pores superficial $c a$. $0.3 \mathrm{C}$ apart with dozen or more setae between. GMs weak, crescent-shaped pads paired in $17 / 18 \& 18 / 19$ just median to male pore line.

Septa strong in anterior and all present. Oesophageal gizzard in 8 . Spermathecae in $8 \& 9$ as elongate ampulla undifferentiated from duct with stumpy clavate diverticulum $1 / 3$ as long ectally. Holandric. Testis in 10 \& 11; seminal vesicles in $11 \& 12$. Last hearts in 13. Ovaries in 13. Prostates racemose on short duct in 18. Calciferous glands absent; intestine in 19; caeca absent. Intestinal gizzards appearing in 26-32 (four in series) highly muscularized and each preceded by equisized, flaccid crop. Typhlosole not found. Nephridia meroic in anterior with eight pairs per segment, just one pair visible $>18 / 19$.

Etymology. After type locality and only known location, Barangay Adya.
Remarks. Easton (1979: 115) combined jagori and samariensis Michaelsen, 1892, ternatae Michaelsen, 1896 plus sivickisi Stephenson, 1933 under Pl. horsti Beddard, 1886 whereas James (2006) - while questioning such synonymy but offering no resolution - proposed more than a dozen new species that are themselves mostly similar (many synonymous?). Male pores in current taxon (0.3C) are wider than Easton's horsti (ca. 0.25) and out of range (0.11-0.18C) of all of James' six species with four gizzards.

Crescentic marking are similar to those of generotype $\mathrm{Pl}$. horsti, but the other GMs are lacking (possibly not fully developed) and the four intestinal gizzards appear within 26-32 rather than just 26-28,29. Compared to James' (2006: tab. 1), closest match is perhaps with $\mathrm{Pl}$. bicolensis from Bicol, Luzon that, however, is darker with dorsal pores from 12/13, gizzards in 27-30 (i.e., not so extensive), and a dozen nephridia per segment.

DNA data unfortunately unobtainable due to prolonged and avoidable delay in UPV sending tissue samples to the lab.

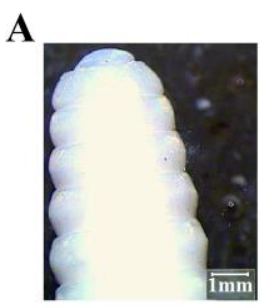

C

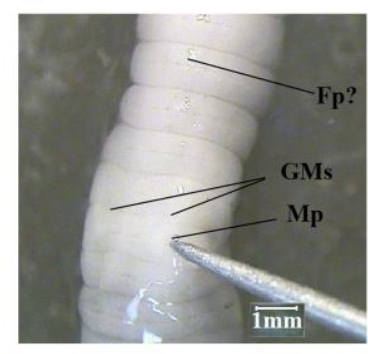

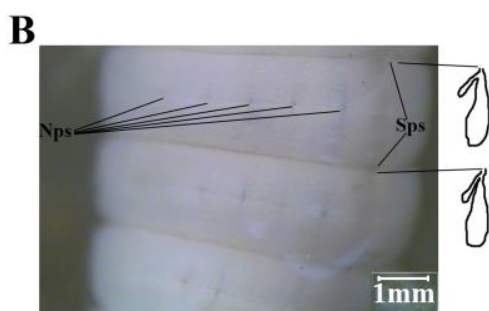

D

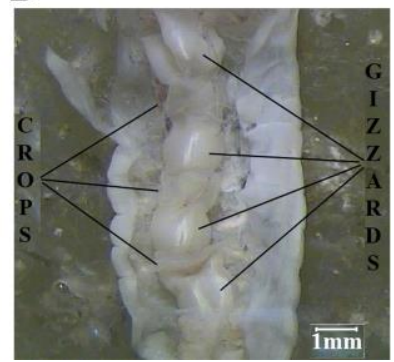

Figure 11. Pleionogaster adya sp. nov. Holotype. A = Prostomium; B = Spermathecal field X3 with sketch of spermathecae; $\mathrm{C}=$ Male field; $\mathrm{D}=$ intestinalgizzards in $26-32$. 


\section{Pleionogaster miagao sp. nov.}

(Figures 1, 12A-H)

Material examined. UPV\#S7: Holotype, mature posterior amputee (dissected and providing genseq-1 DNA sample M1) from clay soil Brgy. Cagbang, Miagao (ca. $10^{\circ} 39^{\prime} \mathrm{N} 122^{\circ} 14^{\prime} \mathrm{E}$ ), Iloilo, Panay Island. Coll. Jover Nuevaespana, Jess \& King from Sulu Garden (Poseidon Sciences) $6^{\text {th }}$ Feb., 2014.

Description. Unpigmented, clitellum yellowy in $14-16$ ventrally and $14-1 / 217$ dorsally. Length $150(+25$ bulbous tail $)=175 \mathrm{~mm}$ by $6 \mathrm{~mm}$. Segments $153(+25)=178$. Prostomium prolobous (with pharynx everted). First dorsal pore 11/12. Setae numerous $>100$ per segment. Nephropores equatorial (fourteen to eighteen per segment in anterior). Spermathecal pores with puckered lips in 7/8/9 ca. 0.2C apart. Female pores below crease on 14. Male pores on round porophores as large puckered slits with $c a$. ten setae between the mounds. GMs represented by broad V-shaped papillae on mid-ventral pad in 16/17 just above setae arc, ellipsoid papillae paired postsetally in 17, broad insunk patches paired below male pores on 18 , corresponding weaker pair of presetal papillae in $19 \& 20$ too, then weaker yet in $21-23$ - these latter tapering as unpapillated pads.

Peptonephridial masses in $4 \& 5$. Septa 5/6/7/8 thickened, thereafter thin. Oesophageal gizzard weak in 8 . Spermathecae in $8 \& 9$ as elongate ampulla on short muscular duct with stumpy clavate diverticulum $1 / 4$ as long ectally. Holandric. Testis in sacs in 10 \& 11; seminal vesicles 11 \& 12 (at least) last pair in 12 with digitiform diverticulum dorsally. Commissurals in 4-9, hearts 1013. Ovaries fan-shaped sheets in 13; no ovisacs in 14. Prostates crescentic on short duct in 18. Calciferous glands absent; intestine in 19; intestinal caeca absent. Intestinal gizzards in 27-30 (four of) greatly distending segment lengthways with intraseptal crop preceding each. Typhlosole lamellate from $c a$. 60 . Gut contains very fine silty clay without organic material suggesting geophagy. Nephridia meroic, $c a$. eight pairs per segment in anterior.
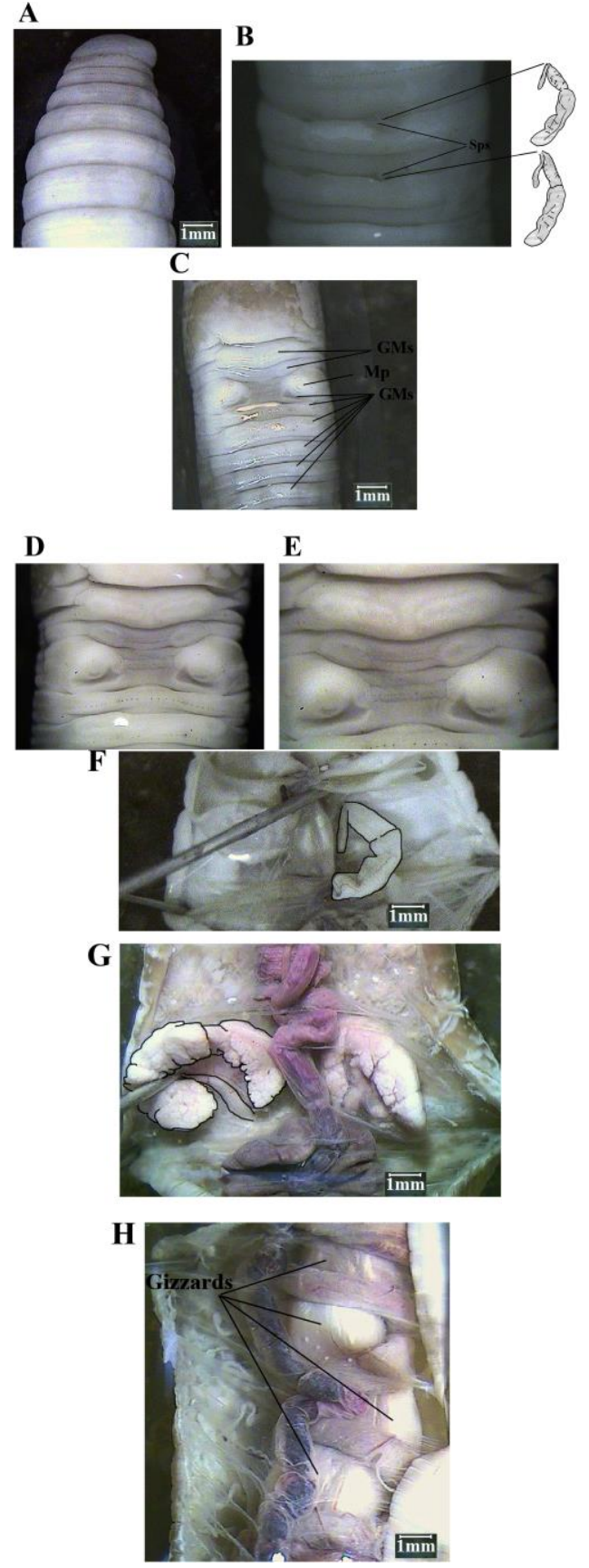

Figure 12. Pleionogaster miagao sp. nov. Holotype. A = Prostomium; $\mathrm{B}=$ Spermathecal field $\mathrm{X} 2$ with sketch of spermathecae; $\mathrm{C}=$ Male field X1; D-E Ditto X2-3; F = Spermathecae 8rhs next to oesophageal gizzard; $\mathrm{G}=$ Prostates, that on $18 \mathrm{lhs}$ outlined and overlain by dorsal blood vessel; $\mathrm{H}=$ Intestinal gizzards in 27-30 and lhs meganephridia.

Etymology. After type locality and only known location, Miagao township, Panay. 
Remarks. Differences from Pl. horsti (Beddard, 1886) are that this often has mid-ventral GMs and the intestinal gizzards are confined in 26-28,29 according to Easton (1979: 115, fig. 46). Closest match with James (2006: tab. 1) is perhaps with $\mathrm{Pl}$. tiwiensis from Tiwi, Luzon that has four intestinal gizzards variable in " $x x v i i-x x x(4), x x v$ xxviii (1)", i.e., in either 27-30 or 25-28; however, it is smaller (94-103 mm) and its spermathecae are $0.08 \mathrm{C}$ apart and male pores $0.12 \mathrm{C}$ apart with "5-6 setae between male pores" ( $c$ f. only four shown in his fig. 1A), fewer nephridia (6$10 /$ segment), no diverticula to seminal vesicles in 12 , typhlosole from "xlvii" and diverticulum about half the length of the spermatheca. Insufficient time/funds were available to further describe another Pleionogaster sp. n. $(1=25-27$ $\mathrm{mm} \#$ \#32) from next to Sulu Gardens, Miagao.

mtDNA COI barcode (KT626595) here provides for the first time a definitive identification of a new Pleionogaster species.

Acknowledgements - Dr Chris Glasby, Curator at Museum and Art Gallery of NT (MAGNT), is thanked for facilitating study of their earthworm collection. Mr Bryan Harty, Director of the Botanic Gardens allowed access to gardens and permaculture terraces. In Philippines, property owners Messrs. Manuel "Nonong" Bagatsing and Ramon "Mon" Peñalosa kindly allowed sampling, while Jonathan Matias of Sulu Gardens gave support. DNA analyses (attempted on UPV delayed material) were by Dr Seunghan Lee of Hanyang Uni., Seoul; whereas Darwin samples were sequenced by Prof Chris Austin and Han Ming Gan at Monash University Malaysia Genomics Facility, Selangor; Dr Duc Anh Nguyen of Hanoi kindly sent me a copy of relevant parts of Omodeo's saigonensis paper.

\section{REFERENCES}

Altschul, S.F., Gish, W., Miller, W., MYers E.W. \& LIPMAN, D.J. (1990): Basic local alignment search tool. Journal of Molecular Biology, 215: 403-410. doi: 10.1016/S0022-2836(05)80360-2

BAHL, K.N. (1919): On a new type of nephridia found in Indian earthworms of the genus Pheretima. Quarterly Journal of Microscopial Science, 64: 57120.

BEDDARD, F.E. (1890): Observations upon an American species of Perichaeta, and upon some other members of the genus. Proceedings of the Zoological Society of London, 1890: 52-69.

BEDDARD, F.E. (1900): A revision of the earthworm genus Amyntas. Proceedings of the Zoological Society, London, 1900: 609-652. doi: $\underline{10.1111 / \mathrm{j} .1096-3642.1890 . t b 01727 . \mathrm{x}}$

BEDDARD, F.E. (1906): Annelida. Oligochaeta. Additional Series, Kew, 5: 66-67.

BEDDARD, F.E. (1912): The oligochaeta terricolae of the Philippines. Part 1. The genus Pheretima. Philippines Journal of Science (series D), 7: 79-203.

BLAKEMORE, R.J. (1994): Earthworms of south-east Queensland and their agronomic potential in brigalow soils. $\mathrm{PhD}$ thesis, University of Queensland, $605 \mathrm{pp}$.

BLAKEMORE, R.J. (1995): Curatorial register of Australian National Earthworm Collection specimens lodged in ANIC, Canberra. Online: www.annelida.net/earthworm/Australasian\%20Earthworms/Register.xls

BLAKEMORE, R.J. (1999): The diversity of exotic earthworms in Australia - a status report. In. PONDER W., LunNEY D. (Eds.) Proceedings of "The Other 99\%”. Transactions of the Royal Zoological Society of NSW, 1999: 182-187.

BLAKEMORE, R.J. (2000): Tasmanian Earthworms. CD-ROM Monograph with review of World families. VermEcology, PO BOX 414 Kippax 2615. Canberra, 800 pp.

BLAKEMORE, R.J. (2002): Cosmopolitan Earthworms an Eco-Taxonomic Guide to the Peregrine Species of the World. VermEcology, Kippax, ACT, Australia, $506 \mathrm{pp}$.

BLAKEMORE, R.J. (2003): Japanese Earthworms (Annelida: Oligochaeta): a Review and Checklist of Species. Organisms, Diversity and Evolution, 3(3): 241-244. doi: 10.1078/1439-6092-00082

BlaKemore, R.J. (2008a): Chapters. In. BlAKEMORE, R.J. (Ed.) A Series of Searchable Texts on Earthworm Biodiversity, Ecology and Systematics from Various Regions of the World - Supplemental. Online: www.annelida.net/earthworm

BLAKEMORE, R.J. (2008b): An updated checklist of pheretimoids (e.g. Amynthas, Duplodicodrilus, Metaphire, Pheretima, Polypheretima, etc.). Online: www.annelida.net/earthworm/Pheretimoids.pdf. 
BLAKEMORE, R.J. (2008c): A definitive checklist of Australian earthworms (Annelida, Oligochaeta: Moniligastridae, Ocnerodrilidae, Acanthodrilidae, Octochaetidae, Benhamiinae, Exxidae?, Megascolecidae, Glossoscolecidae, Lumbricidae, Eudrilidae).

Online:www.annelida.net/earthworm/Australasian \%20Earthworms/Aussie\%20Earthworms.pdf.

BLAKEMORE, R.J. (2009): Cosmopolitan earthworms a global and historical perspective. In. SHAIN, D.H. (Ed.) Annelids as Model Systems in the Biological Sciences. John Wiley \& Sons, Inc., N.Y. p. 257283. doi: $10.1002 / 9780470455203 . c h 14$

BlaKemORE, R.J. (2010): Saga of Herr Hilgendorf's worms. Zoology in the Middle East, 49: 7-22. doi: 10.1080/09397140.2010.10638453

BLAKEMORE, R.J. (2011): Description of a new Amynthas earthworm (Megascolecidae s. s.) from Thailand. Bulletin of the National Museum of Nature and Science, Tokyo Series A, 37(1): 9-13.

BLAKEMORE, R.J. (2012a): Cosmopolitan Earthworms. $5^{\text {th }}$ Edition. VermEcology, Yokohama, CD-ROM Monograph, 990 pp.

BLAKEMORE, R.J. (2012b): New earthworm species from NIBR's Jeju-do biosphere compared to historical and new Japanese types (Oligochaeta: Megadrilacea: Megascolecidae). Journal of Species Research, 1(2): 133-115. doi: 10.12651/JSR.2012.1.2.133.

BLAKEMORE, R.J. (2013a): The major megadrile families of the World reviewed again on their taxonomic types (Annelida: Oligochaeta: Megadrilacea). Opuscula Zoologica Budapest, 44(2): 107-127.

BLAKEMORE, R.J. (2013b): Jeju-do earthworms (Oligochaeta: Megadrilacea) - Quelpart Island revisited. Journal of Species Research, 2(1): 15-54. doi : $\underline{10.12651 / J S R .2013 .2 .1 .015}$

BLAKEMORE, R.J. (2015): Eco-taxonomic profile of an iconic vermicomposter - the 'African Nightcrawler' earthworm Eudrilus eugeniae (Kinberg, 1867). African Invertebrates, 56(3): 527-548.

Blakemore, R.J., Csuzdi, Cs., ITO, M.T., KaneKo, N., KAwAguchi, T. \& Schilthuizen, M. (2007a): Taxonomic status and ecology of Oriental Pheretima darnleiensis (Fletcher, 1886) and other earthworms (Oligochaeta: Megascolecidae) from Mt Kinabalu, Borneo. Zootaxa, 1613: 23-44. doi: 10.11646/zootaxa.3881.5.1.
Blakemore, R.J., Csuzdi, Cs., ITO, M., KANEKo, N., PAOletTI, M.G., SPIRIDONOV, S.E., UCHIDA, T. \& VAN PRAAGH, B.D. (2007b): Megascolex (Promegascolex) mekongianus Cognetti, 1922: its extent, ecology and allocation to Amynthas (Oligochaeta: Megascolecidae). Opuscula Zoologica Budapest, 36: 19-30.

BlaKemore, R.J., KuPRIYANOVA, E. \& GRYGIER, M.J. (2010): Neotypification of Drawida hattamimizu Hatai, 1930 (Oligochaeta: Megadrili: Moniligastridae) as a model linking mtDNA (COI) sequences to an earthworm type, with a response to the 'Can of Worms' theory of cryptic species. ZooKeys, 41: 129. doi: $10.3897 /$ zookeys.41.374

BlaKemore, R.J., LEE, S. \& SEO, H.-Y. (2014): Reports of Drawida (Oligochaeta: Moniligastridae) from far East Asia. Journal of Species Research, 3(2): 127-166. doi: 10.12651/JSR.2014.3.2.127

CHEN, Y. (1938): Oligochaeta from Hainan, Kwangtung. Contributions from the Biological Laboratory of the Science Society of China. Zoological Series, 12 (10): 375-427.

CognetTi, D.M.L. (1922): Descrizione di tre nuovi megascolecini. Bollettino dei Musei di Zoologia et Anatomia comparata della Reale Universita di Torino, 37: 1-6.

DARWIN, C. (1881): The Formation of Vegetable Mould through the Action of Worms with Observations on their Habits. Murray, London $326 \mathrm{pp}$. doi: 10.5962/bhl.title.21214

DYNE, G.R. (1987): Two new acanthodriline earthworms (Oligochaeta : Megascolecioidea) from the Northern Territory, Australia. The Beagle, 4(1): 1-6.

DYNE, G.R. \& JAMIESON, B.J. (2004): Native Earthworms of Australia II (Megascolecidae, Acanthodrilinae). [sic]. ABRS, Canberra. (CD-ROM), 200 pp.

EASTON, E.G. (1976): Taxonomy and distribution of the Metapheretima elongata species-complex of Indo-Australasian earthworms (Megascolecidae: Oligochaeta). Bulletin of the British Museum (Natural History) Zoology, 30(2): 29-53. doi: 10.5962/bhl.part.2374

EASTON, E.G. (1979): A revision of the 'acaecate' earthworms of the Pheretima group (Megascolecidae: Oligochaeta): Archipheretima, Metapheretima, Planapheretima, Pleionogaster and Polypheretima. Bulletin of the British Museum (Natural History) Zoology, 35(1): 1-128. 
EASTON, E.G. (1982): Australian pheretimoid earthworms (Megascolecidae: Oligochaeta): a synopsis with the description of a new genus and five new species. Australian Journal of Zoology, 30, 711735. doi: $10.1071 / \mathrm{ZO} 9820711$

GATES, G.E. (1925): LXXI. - Notes on Rosa's Rangoon earthworms, Pheretima peguana and Eutyphoeus foveatus. Journal of Natural History, [9] 16(95): 561-577. doi: 10.1080/00222932508633349

GATES, G.E. (1937): Notes on some species of Drawida and Pheretima with descriptions of three new species of Pheretima. Bulletin of the Museum of Comparative Zoology, 80(7): 305-335.

GATES, G.E. (1972): Burmese earthworms, an introduction to the systematics and biology of megadrile oligochaetes with special reference to the Southeast Asia. Transactions of the American Philosophical Society, 62: 1-326. doi: 10.2307/1006214

HANLEY, J.R. (1993): The marine flora and fauna of Darwin Harbour, Northern Territory, Australia. Proceedings of the Sixth International Marine Biological Workshop. Museum \& Art Gallery of the N.T., Darwin, 466 pp.

Hebert, P.D.N., Cywinska, A., BALl, S.L. \& DE WAARD, J.R. (2003): Biological identifications through DNA barcodes. Proceedings of the Royal Society, B, 270: 313-321. doi: 10.1098/rspb.2002.2218

HONG, Y. \& JAMES, S.W. (2008): Nine new species of earthworms (Oligochaeta: Megascolecidae) of the Banaue rice terraces, Philippines. Revue Suisse de Zoologie, 115: 341-354. doi: 10.5962/bhl.part.80431.

HoNG, Y. \& JAMES, S.W. (2010): Six new earthworms of the genus Pheretima (Oligochaeta: Megascolecidae) from Balbalan-Balbalasang, Kalinga Province, the Philippines. Zoological Studies, 49: 523533.

HONG, Y. \& JAMES, S.W. (2011a): New species of Pheretima, Pithemera, and Polypheretima (Clitellata: Megascolecidae) from Kalbaryo, Luzon Island, Philippines. Raffles Bulletin of Zoology, 59: 19-28.

HoNG, Y. \& JAMES, S.W. (2011b): New earthworm species of the genus Pheretima (Clitellata: Megascolecidae) from Mountain Province, Philippines. Journal of Natural History, 45: 1769-1788. doi: $10.1080 / 00222933.2011 .560726$

JAMES, S.W. (2006): The earthworm genus Pleionogaster (Clitellata: Megascolecidae) in southern
Luzon, Philippines. Organisms Diversity \& Evolution, 6(3): 167-170. doi: $10.1016 /$ j.ode.2005.08.003

KVIST, S. (2014). Does a global DNA barcoding gap exist in Annelida? Mitochondrial DNA. 4: 1-12. doi: 10.3109/19401736.2014.984166

LOONGYAI ,W., BANGRAK, P. \& ChANTSAVANG, S. (2011): External morphological comparison, taxonomic revision and molecular differentiation of the four economically important species of earthworms in Thailand. International Journal of Agriculture \& Biology, 13(4): 553-558.

MICHAELSEN ,W. (1899): Terricolen von verschiedenen Gebieten der Erde. Jahrbuch der Hamburgischen wissenschaftlichen Anstalten, 16: 1-122.

Michaelsen ,W. (1900): Das Tierreich Vol. 10: Oligochaeta. Friedländer \& Sohn, Berlin, xxix +575 pp. doi: 10.5962/bhl.title.1108.

MichAELSEN ,W. (1913): Oligochäten von Travancore und Borneo. Mitteilungen aus dem Naturhistrischen Museum in Hamburg, 30(2): 73-92.

MiCHAELSEN ,W. (1922): Oligochäeten aus dem Rijks museum van natuurlijke historie zu Leiden. Capita Zoologica, 1: 1-72.

MiCHAELSEN ,W. (1934): Oligochäten von Französisch-Indochina. Archives de Zoologie Expérimentale et Générale, Paris, 76: 493-546.

NGUYEN, T.T. (2011): Descriptions of two new species of earthworm of the genus Pheretima Kinberg, 1867 (Oligochaeta: Megascolecidae) from Mekong Delta - Vietnam. Tap Chi Sinh Hoc (Journal of Biology), 33(1): 24-29. doi: $10.15625 / 0866-7160 / \mathrm{v} 33 \mathrm{n} 1.730$.

NGUYEN, T.T. (2013): The earthworm fauna of the Cuu Long River Delta, Vietnam. Unpublished $\mathrm{PhD}$ thesis, Hanoi National University of Education, Vietnam, $169 \mathrm{pp}$.

NGUYEN, T.N.N. (2014): Species and distribution characteristics of earthworms in Dau Tieng District, Binh Duong Province. Journal of Thu Dau Mot University, 5(18): 48-54.

NGuYEn, T.T., Dung, T.N. \& PHAM, M.T. (2012): Testing on three determining methods of genetic diversity on earthworm species belonging to the Pheretima species group in the Mekong delta. Nguyen Thanh Tung. Tap Chi Sinh Hoc (Journal of Biology), 34(1): 6-14. doi: $10.15625 / 0866-7160 / v 34 n 1.664$. 
OMODEO, P. (1956): Oligocheti dell'Indocina e del Mediterraneo Orientale. Memorie del Museo Civico di Storia Naturale di Verona, 5: 321-336.

OMODEO, P. (2000): Evolution and biogeography of megadriles (Annelida, Clitellata). Italian Journal of Zoology, 67: 179-201. doi: $10.1080 / 11250000009356313$

PERRIER, E. (1872): Recherches pour servir à l'histoire des lombriciens terrestres. Nouveaux Archives $d u$ Muséum National d'Histoire Naturelle, Paris, 8: 5198. doi: 10.5962/bhl.title.12201.

RosA, D. (1890): Viaggio di Leonardo Fea in Birmanica e regioni vicine, XXVI. Perichaetidi. Annali del Museo Civico di Storia Naturale, Giacomo Doria, 10: 107-122. doi: 10.5962/bhl.title.48832.

RosA, D. (1891): Die exotischen terricolen des k. k. naturhistorischen Hofmuseums. Annelen des Naturhistorischen Museums in Wien, 6: 379-406.

RosA, D. (1898): On some new earthworms in the British Museum. Annals and magazine of Natural History, 7(2): 276-290. doi: $\underline{10.1080 / 00222939808678045}$

ReFuerzo, P.G. \& REYes, P.V. (1959): Studies on Metastrongylus apri. I. The earthworm host in the Philippines. Philippine Journal of Animal Industry, 19: $55-62$

Siddall, M.E., ApaKupaKul, K., Burreson, E.M., COATES, K.A., ERséUs, C., GELdER, S.R., KÄLLERSJÖ, M. \& TRAPIDO-ROSENTHAL, H. (2001): Validating Livanow's Hypothesis: Molecular Data Agree that Leeches, Branchiobdellidans and Acanthobdella peledina form a Monophyletic Group of Oligochaetes. Molecular Phylogenetics and Evolution, 21: 346-351. doi. 10.1006/mpev.2001.1021

SIMS, R.W. \& EASTON, E.G. (1972): A numerical revision of the earthworm genus Pheretima auct. (Megascolecidae:Oligochaeta) with the recognition of new genera and an appendix on the earthworms collected by the Royal Society North Borneo Expedition. Biological Journal of the Linnean Society, 4: 169-268. doi: 10.1111/j.1095-8312.1972.tb00694.x

SIVICKIS, P.B. (1930): Distibution of setae in the earthworm Pheretima benguetensis Beddard. Biological Bulletin, 58(3): 274-280. doi: 10.2307/1537106.

SOMniYAM, P. (2008): The Diversity and Distribution of Terrestrial Earthworms in Sakaerat Environmental Research Station and Adjacent Areas, Nak- hon Ratchasima, Thailand. Unpublished PhD Thesis, Suranaree University of Technology, 214 pp.

Somniyam, P., SuWANwaree, P. (2009): The Diversity and Distribution of Terrestrial Earthworms in Sakaerat Environmental Research Station and Adjacent Areas, Nakhon Ratchasima, Thailand. World Applied Sciences Journal, 6: 221-26

STEPHENSON, J. (1923): Oligochaeta. In. SHIPLEY, A.E. and ScOTT, H. (Eds.) The Fauna of British India including Ceylon and Burma. Taylor \& Francis, London, $518 \mathrm{pp}$.

TAMURA K. \& NEI M. (1993): Estimation of the number of nucleotide substitutions in the control region of mitochondrial DNA in humans and chimpanzees. Molecular Biology and Evolution, 10: 512-526.

TAmura K., Stecher G., Peterson D., FiliPski A. \& KUMAR S. (2013): MEGA6: Molecular Evolutionary Genetics Analysis version 6.0. Molecular Biology and Evolution, 30: 2725-2729. doi: $10.1093 / \mathrm{molbev} / \mathrm{mst} 197$

TIMM, T. (2012): About the scientific names of paraphyletic taxa. Turkish Journal of Zoology, 36(1): 139-140. doi: 10.3906/zoo-1002-52

THAI, T.B. (2000): Species Diversity of earthworms in Vietnam. Nhung Van De Nghien Cuu Co Ban Trong Sinh Hoc, 2000: 307-311. [Vietnamese: Thái Trần Bái (2000) Đa dạng loài giun đất ở Việt Nam, Những vấn đề nghiên cúu co bản trong sinh học, Đại học quốc gia Hà Nội, 2000: 307 -311].

THAI, T.B. \& Do, V.N. (1989): Remarks on earthworm fauna in Phnom Penh and the neighboring regions. Thong Bao Khoa Hoc (Hanoi), 1989: 76-79.

THAI, T.B. \& SAMPHON, K. (1989): Initial remarks on the fauna of earthworms in Laos. Thong Bao Khoa Hoc (Hanoi), 1989: 61-75. [Vietnamese: Thái TB, Samphon K (1989) Nhận xét bước đầu về khu hệ giun đất Lào (từ cao nguyên Mường Phuôn đến cao nguyên Bua La Vên). Thông báo khoa học ĐHSPHN, 1: $61-75]$.

THAI, T.B. \& SAMPHON, K. (1991): Earthworms of some regions skirting the middle part of Mekong river in Laos (from Vientiane to Pacse). Tap Chi Sinh Hoc (Journal of Biology), 22 (1): 1-5.

VAILlANT, L. (1868): Note sur I'anatomie de deux especes du genre Perichaeta et essai de classification des Annelides Lombricines. Annales des Sciences Naturelles, 10: 225-256. 